\title{
Lower crust exhumation during Paleoproterozoic (Eburnean) orogeny, NW Ghana, West African Craton: interplay of coeval contractional deformation and extensional gravitational collapse.
}

Sylvain Block ${ }^{1}$, Mark Jessell ${ }^{2}$, Laurent Ailleres ${ }^{3}$, Lenka Baratoux ${ }^{1}$, Olivier Bruguier ${ }^{4}$, Armin Zeh $^{5}$, Delphine Bosch, Renaud Caby.

${ }^{1}$ Geosciences Environnement Toulouse, Observatoire Midi Pyrénées, 14 ave E. Belin, 31400, Toulouse, France.

${ }^{2}$ Center for Exploration Targeting, The University of Western Australia, 35 Stirling Highway, Crawley, Perth, Western Australia 6009

${ }^{3}$ Monash University, School of Geosciences, Wellington Road, Clayton, Vic 3800, Australia

${ }^{4}$ Universite Montpellier 2-CNRS, cc 066, Place Eugène Bataillon,34095 Montpellier Cedex 5, France.

${ }^{5}$ Institut für Geowissenschaften, Altenhöfer Allee 1, D-60438 Frankfurt am Main, Germany.

\section{Abstract}

We present a new litho-structural and metamorphic map of the Paleoproterozoic (2.25-2.10 Ga) West African Craton in northern Ghana, based on the interpretation of field observations and airborne geophysical datasets. It reveals contrasting metamorphic domains consisting of high-grade gneisses and low-grade volcano-sedimentary belts, separated by shear zones and brought together during the Paleoproterozoic Eburnean orogeny (2.15-2.10 Ga). Supracrustal rocks and intrusives were buried and metamorphosed under amphibolite- to granulite facies conditions, during a (D1) deformation event consistent with N-S horizontal shortening, and associated with reverse shear zones. High and low metamorphic grade rocks are brought in contact along extensional shear zones formed during N-S extension (D2). These are overprinted by constrictional deformation associated with E-W shortening (D3), formed under high-grade metamorphic conditions. Late-stage tectonic evolution (D4-D7) consists of strain localisation in multiple generations of narrow shear zones, and re-activation of inherited structures in a dominantly transcurrent regime. U-Pb dating of zircon and monazite from magmatic and metamorphic rocks reveals that D1-D3 deformation forms a continuous and overlapping time sequence. Coeval lower and upper crustal units witnessed a continuous tectonic evolution from ca. 2140 to 2110 
Ma, characterised by changing tectonic styles and strain fields. The shift from horizontal tectonic forces to dominant gravitational forces allows for the exhumation of the lower crust in anatectic migmatite domes. We suggest that doming is accommodated by lateral extensional sliding of the upper crust and amplified by coeval orthogonal shortening. The rapid shift in shortening directions points to a change in boundary conditions applied to the orogeny. We hypothesise that it is due to the collision of northern Ghana with the Paleoproterozoic province in modern-day southern Burkina Faso, which shows contrasting litho-tectonic features. The evolution of the Eburnean orogeny in NW Ghana reveals that it shared thermo-mechanical similarities with modern orogenic belts. The findings bring new insight in Paleoprotezozoic plate tectonics, at the transition between archaic and modern geodynamics.

\section{Introduction}

The applicability of the plate-tectonics paradigm to the early Earth is subject to much controversy, due to divergent interpretations derived from observations carried out on Archean cratons (Windley, 1992; de Wit and Ashwal, 1997; Condie, 1998; Condie and Pease, 2008; Cawood et al., 2006; 2009). Granitegreenstone terranes, made of TTG (tonalite, trondhjemite, granodiorite) suites, alternating with narrow volcano-sedimentary belts, exposing large surfaces affected by homogeneous, distributed strain, and transect by craton-scale strike-slip shear zones, have in turns been described as the result of "modernstyle” subduction-driven plate tectonics, dominated by lateral displacements (e.g. de Wit, 2004; Condie and Kröner, 2008); or as a consequence of “archaic” geodynamic processes, dominated by body forces and vertical displacements (e.g. de Wit, 1998; Hamilton, 1998, 2003; Van Kranendonk et al., 2004, 2007; Stern, 2005).

The literature contains abundant descriptions of features from Archean and Paleoproterozoic provinces interpreted as being subduction-related (e.g. ophiolites or accretionary prisms, Komiya et al., 1999; Kusky et al., 2001). However, evidence for fold and thrust belts, blueshist and Ultra-High Pressure metamorphism, extensional gravitational collapse structures, which characterise Phanerozoic orogenic belts (e.g. Miyashiro, 1961; Dewey, 1988; Chopin, 2003; Brown, 2009) are lacking. The contrasted 
geological record between Archean and Phanerozoic provinces has led a growing body of research to point out the limits of a strictly uniformitarian approach to geodynamics of the early Earth. Within the plate-tectonic framework, theoretical considerations on the secular thermal evolution of the Earth suggest that plate-tectonics would have operated differently relative to modern geodynamics, as inferred hotter mantle temperatures have strong implications on surface heat flux, subduction viability (e.g. Korenaga, 2006, van Hunen and van den Berg, 2008), and on deformation styles (e.g. Rey and Houseman, 2006). Furthermore, other authors have emphasised that the interpretation of geological data in terms of geodynamics is non-unique, and alternative frameworks to plate tectonics have been proposed (e.g. Hamilton, 1998; Bédard et al., 2003, Bédard, 2013).

Although much of the debate has focussed on the Archean, the controversy lives on in the Paleoproterozoic. Indeed, monotonous distributed regional strain and homogeneous LP-HT metamorphic patterns are reported in Proterozoic accretionary "hot” orogens, while they lack some structural and metamorphic characteristics of modern orogenic belts (e.g. Cagnard et al., 2007, Chardon et al., 2009; Vidal et al., 2009). However, despite geochemical, lithological and structural similarities with Archean provinces, Proterozoic accretionary orogens have a specific metamorphic record, characterized by a duality of thermal regimes, inferred from rocks metamorphosed along distinct apparent geothermal gradients (Brown, 2009). The geological record of Proterozoic accretionary orogens may therefore reflect geodynamic contexts which differ both from Archean and Phanerozoic settings, and which represent a distinct, transitional phase in the secular evolution of the Earth.

In order to explore the geodynamic processes at work in the Proterozoic, we draw our attention to the Paleoproterozoic (2.25-2.1 Ga) West African Craton (Abouchami et al., 1990; Boher et al., 1992). It is one of the youngest large $\left(\sim 3.10^{-6} \mathrm{~km}^{2}\right)$ juvenile continental domains produced during a major crustal growth episode. The craton mainly consists of TTG suites (e.g. Gasquet et al., 2003), granites and “Birimian” (Junner, 1940; Bates, 1955, 1956) greenstone belts. It is a key study area for the exploration of the Archean-Proterozoic transition and for our understanding of geodynamic processes in Paleoproterozoic juvenile accretionary orogens.

Our study area, in northwestern Ghana, exposes large surfaces of exhumed high-grade metamorphic rocks juxtaposed to coeval low-grade metamorphic rocks. Detailed lithological, structural and 
metamorphic maps are produced from the interpretation of field and geophysical data. A structural analysis is carried out and coupled to geochronological constraints, in order to describe the deformation sequence during the orogenic cycle. The new dataset helps to characterise the tectonic style of the Eburnean orogeny, constrain exhumation processes, and evaluate the suitability of a collisional orogenic model for the evolution of the Paleoproterozoic craton in north-western Ghana.

\section{1- Geological setting}

The Leo-Man rise (Fig. 1) forms the southern exposure of the West African Craton. It comprises an Archean nucleus, the 3.0-2.5 Ga Kénéma-Man domain, flanked to the North and East by the juvenile Paleoproterozoic Baoulé-Mossi domain. Following magmatic accretion of the continental crust, the Eburnean orogeny (Bessoles, 1977; Lemoine, 1988; Milési et al., 1989, 1991, 1992; Eisenlohr, 1989; Eisenlohr and Hirdes, 1992; Opare-Addo et al., 1993; Chalokwu et al., 1997) led to the tectonic amalgamation of the Archean nucleus and the various Paleoproterozoic domains between 2.15 and 2.08 Ga (Feybesse and Milési, 1994 ; Feybesse et al., 2000 ; Hirdes et al., 1996 ; Lüdtke et al., 1998 ; Feybesse et al., 2006). 


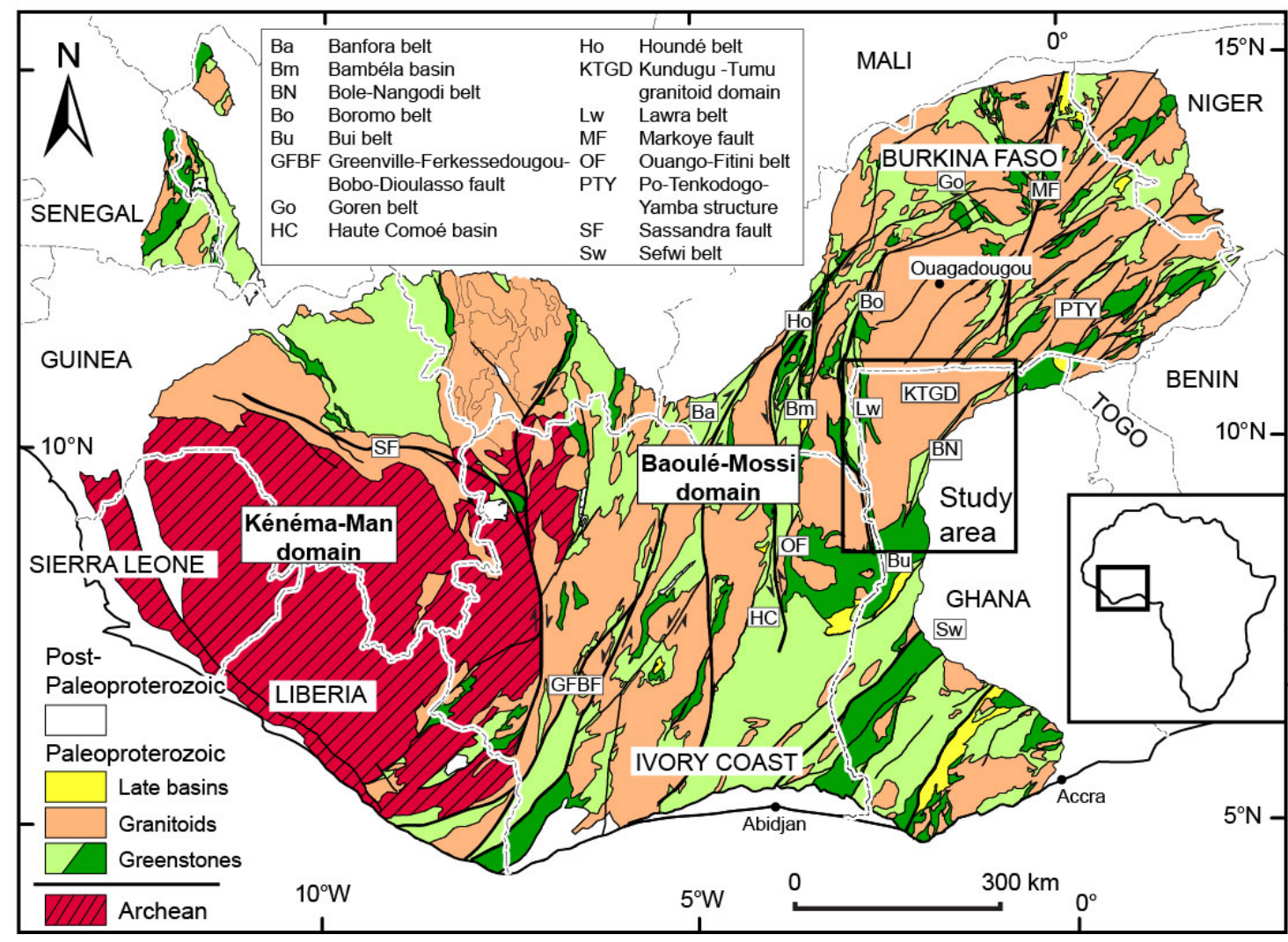

Figure 1. Simplified geological map of the Leo-Man craton (modified after the BRGM SIGAfrique map, Milesi et al., 2004), indicating the study area. Light and dark green show intermediate to acidic volcanosediments or volcanoclastites, and mafic volcanics respectively.

A polycyclic orogenic evolution model is suggested on the basis of field relationships reflecting polyphase structural-metamorphic fabrics in various parts of the craton (Arnould, 1961; Bard and Lemoine, 1976, Ledru et al., 1991). The gneissic basement supposedly pre-dating the Birimian series is termed “Antébirrimian” (Roques, 1948; Sagatzky, 1954; Arnould, 1961) or “Dabakalian” (Tempier, 1986; Lemoine et al., 1990). Dabakalian and Birimian formations are considered to be separated in time by an early deformation event affecting the basement, named "Tangaean” (Tshibubudze et al., 2009; Hein, 2010) or "Burkinian” (Lemoine et al., 1990) in Burkina Faso and Côte d’Ivoire. They are grouped under the general term of Eoeburnean (De Kock et al., 2011; 2012, Baratoux et al., 2011; Perrouty et al.; 2012), designating the early tectonic evolution between 2.2 and $2.15 \mathrm{Ga}$, which is interpreted to take place before the Eburnean orogeny sensu stricto. However, this model has been challenged by other authors 
(e.g. Leube et al., 1990, Eisenlohr and Hirdes, 1992, Hirdes et al., 1996, Gasquet et al., 2003, Block et al ?) who suggest that the different tectono-metamorphic terrains are coeval and formed during the Eburnean orogeny sensu stricto. . The latter would correspond to the assembly of the Paleoproterozoic domains against the Archean nucleus (Kouamelan et al., 1997). Across the craton, proposed suture zones between potentially distinct terrains (Hirdes et al., 1996) remain ambiguous, and the lack of evidence for clear lateral age gradients (Delor et al., 1995; Doumbia et al., 1998; Lahondère, 2002; Castaing et al., 2003; Théveniaut, 2010; Tapsoba et al., 2013) raises questions on the applicability of lateral accretion crustal-growth models.

The debate on the tectonic regimes dominating the Eburnean orogeny echoes the controversy on Archean geodynamics. Some authors report dome and basin structural patterns, and invoke diapirism or gravity-driven tectonics to account for field observations, e.g. in Ivory Coast and Niger (Vidal et al., 1996, Vidal, 1987; Vidal et al., 1996; Vidal et al., 2009; Hirdes et al., 1992; Nikiéma et al., 1993; Delor et al., 1995a; Pons et al., 1995; Pouclet et al., 1996; Caby et al., 2000). Another school of thought interprets the Eburnean orogenic record as a product of nappe-style tectonics (Milési et al., 1989; Ledru and Milési, 1990; Feybesse and Milési, 1994; Billa et al., 1999, Feybesse et al., 2006). The late-stage evolution of the Eburnean orogeny is characterised by the activation of transcurrent shear zones (e.g. Ledru et al., 1991; Feybesse, 1990; Jessell et al., 2012) localised at the interface between greenstone belts and granite-gneiss terrains.

\section{2- Study area}

The geology of northwestern Ghana is characterised by low- to high-grade tectono-metamorphic domains which are transect or limited by high-strain shear zones (SZ), and are intruded by successive pulses of plutonic rocks.

\subsection{Low-grade volcano-sedimentary belts.}

Low-grade shales, volcano-sedimentary rocks, lavas such as dacites, andesites and basalts are found in 
the N-S Wa-Lawra belt (Fig. 2), which is the south-eastern continuation of the Boromo greenstone belt exposed in Burkina Faso (Baratoux et al., 2011; Metelka et al., 2011). Similar low-grade lithologies are found in the E-W trending Julie belt (Fig. 2), which also comprises silicic volcano-sediments, quartzites and arkoses. The Maluwe basin is a low-grade tectono-metamorphic terrain elongated SW-NE along $\sim 250 \mathrm{~km}$, which tapers off towards the NE to a thin sliver (Fig. 2), although it may extend below the Volta Basin. It is dominated by greywacke and shales which are intercalated with volcanoclastic rocks and felsic to intermediate lavas, deposited between 2197 and 2125 Ma (De Kock et al., 2009; Thomas et al., 2009). It also comprises chemical sediments such as Mn-rich cherts, along with mafic intrusives such as gabbros and pyroxenites. The Nangodi belt (Melcher and Stumpfl, 1994), in the northeastern part of the study area (Fig. 2) is formed by a succession of shales, greywacke and Mn-rich cherts alternating with MORB-type basalts, overlain by calc-alkaline andesitic to rhyolitic lava flows.

\subsection{High-grade metamorphic terrains and granitoid domains.}

The Bole-Bulenga terrain, is a 150 by $20-80 \mathrm{~km}$ long terrain elongated along a NNE direction (Fig. 2), which is formed of high-grade orthogneisses, paragneisses and minor metabasites. The paragneisses are derived from pelites, greywacke and volcano-sedimentary rocks, and are termed "Buki gneisses” by De Kock et al. (2011). They are intruded by TTG and monzogranite orthogneisses with crystallisation ages between 2195 and 2135 Ma. The lithologies of the Bole-Bulenga terrain are frequently migmatitic. The Abulembire terrain shares many lithological and metamorphic similarities with the Bole-Bulenga terrain. It is essentially made of paragneisses, sometimes migmatitic, intruded by TTG and granite orthogneisses, which were emplaced at between ca. 2200 and 2125 Ma (De Kock et al., 2009; Agyei Duodu et al., 2009). The Abulembire terrain is limited to the south by the Bui belt (Zitsmann et al., 1997).

The Koudougou-Tumu granitoid domain (KTGD), extending north in Burkina Faso, comprises abundant migmatitic TTG orthogneisses, and small volumes of mafic orthogneisses and paragneisses. The protolith of some orthogneisses formed between 2163 and 2154 Ma (Agyei Duodu et al., 2009).

The Wa-Lawra granitoid domain (WLGD) forms the eastern margin of the Wa-Lawra belt. It is dominated by granite and granodiorite plutons intrusive in high grade para- and orthogneisses, which 
are predominant to the south of the domain.

The Bawku granitoid domain (BGD) is flanked along the eastern margin of the Nangodi. It mostly consists of deformed granodiorite and granite plutons emplaced between 2170 and 2127 Ma (Agyei Duodu et al., 2009). This domain also comprises small volumes of volcanic rocks as dacites and basalts, which underwent metamorphism at or below the greenschist-amphibolite facies transition.

The Nassian granitoid domain (Delor et al., 1995; Vidal et al., 2009) is found in northeastern Côte d'Ivoire, along the western margin of the Bole-Bulenga terrain. It comprises ca. 2150 Ma orthogneisses and a suite of intrusive granites.

\subsection{Intrusive granitoids}

The litho-tectonic units forming the Wa-Lawra belt, the Bole-Bulenga terrain, the Maluwe Basin and the Abulembire fragment are extensively intruded by biotite granites of the so-called Tanina suite (G4, Fig 2) between 2134 and 2118 Ma (De Kock et al., 2011). Late-stage potassic porphyric granites (G5 in Fig. 2) with crystallisation ages ranging between 2128 and 2086 Ma (Taylor et al., 1992; Agyei Duodu et al., 2009) intrude large swathes of the Koudougou-Tumu granitoid domain. Weakly deformed elliptical syenite and gabbro bodies are found in the Maluwe basin.

\subsection{Major shear zones}

The cratonic architecture in northwestern Ghana is characterised by two major N-S and NE-SW structural trends. The Koudougou-Tumu granitoid domain is separated from the Wa-Lawra granitoid domain by a ductile shear zone striking N150 known as the Jang shear zone. At its northern extent, the Jang SZ merges with the Jirapa SZ, which strikes N160 and extends north into Burkina Faso along most of the length of the Boromo belt. The Jirapa SZ separates low-grade sedimentary and volcanosedimentary rocks to the west from the Wa-Lawra granitoid domain to the east.

At its southern extension, the Jirapa SZ transects the Bole-Bulenga terrain and merges with the NE-SW Bole-Nangodi shear zone (Fig. 2) in an interference zone. From SW to NE, the Bole-Nangodi SZ transects the Bole-Bulenga terrain, forms the boundary between the Bole-Bulenga terrain and the Maluwe basin, before extending along the western margin of the Nangodi belt and into Burkina Faso, 
where it is known as the Po-Tenkodogo-Yamba structure (Naba et al., 2004; Ganne et al., 2011).

These two sets of shear zones overprint or transpose earlier structures. The Julie shear zone, oriented E$\mathrm{W}$, bounds the Koudougou-Tumu granitoid domain to the south and forms the transition zone with the Julie belt to the south. It terminates on the Jang SZ to the west and is transposed to a NE direction at its eastern extension, in the vicinity of the Bole-Nangodi SZ. The Bole-Bulenga shear zone separates the low-grade Julie belt to the north from the Bole-Bulenga terrain to the south, and is transposed into NEstriking shear zones to the east. The Bole shear zone forms the contact between the Bole-Bulenga terrain to the north, and the Maluwe Basin to the south. It is folded and transposed into a later NE-striking shear zone. 


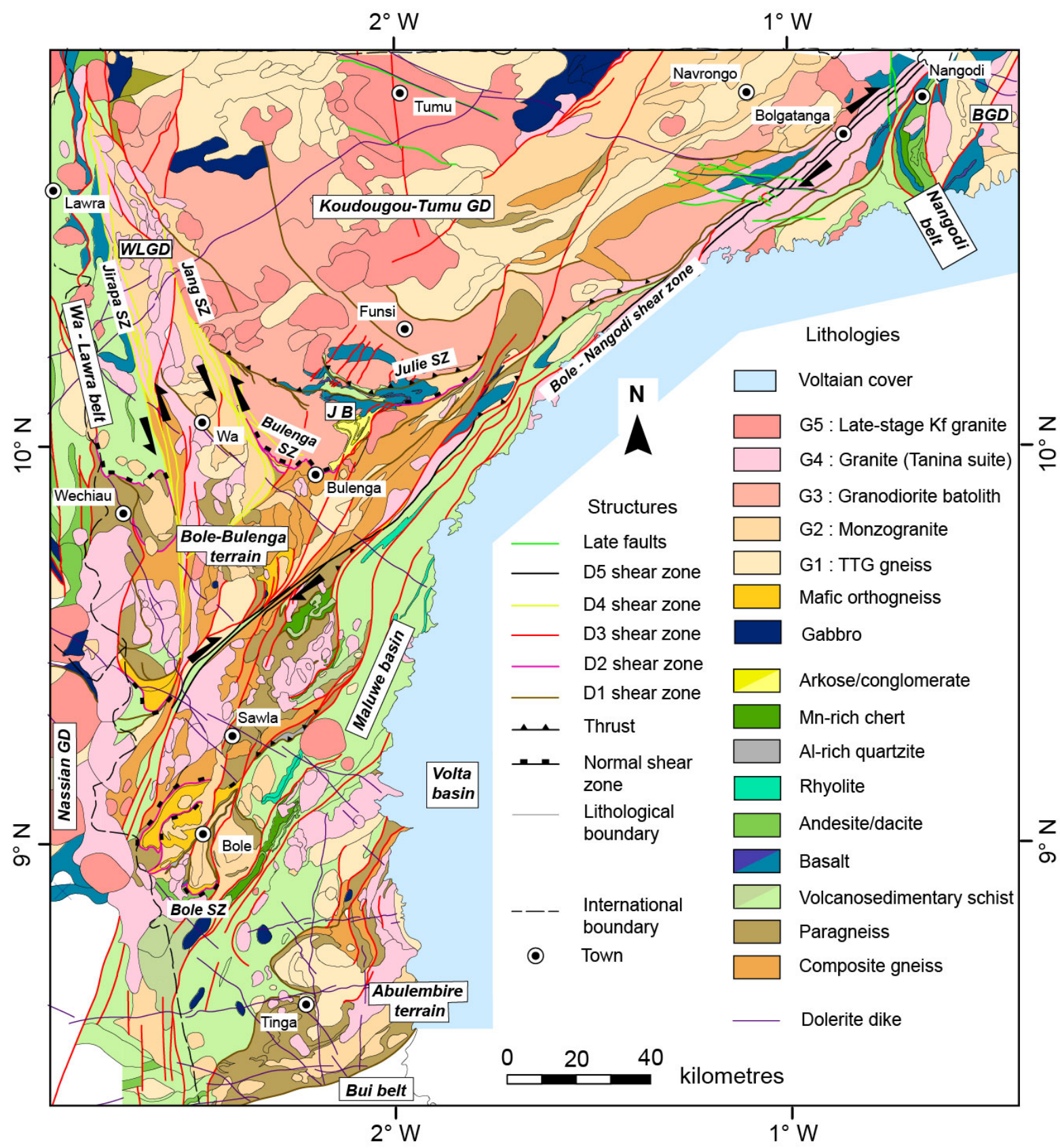

Figure 2: Lithological map of the Paleoproterozoic of northwestern Ghana. BGD: Bawku granitoid domain. JB: Julie Belt; WLGD: Wa - Lawra granitoid domain. GD = granitoid domain, $S Z=$ shear zone. Shear zones are colour-coded in correspondence to the deformation event under which they were last active, i.e. D3 shear zone was formed or last re-activated during deformation D3 (see text). Darker colours used to represent the same lithology designate rocks with distinctively high magnetic response.

\section{3- Mapping methodology}




\subsection{Field and geophysical data}

Lithological, petrological and structural data were collected on a total of 947 observation points, and magnetic susceptibility values were measured for most of the principal rock types in the study area. They were combined with pre-existing observation points acquired during a 1:100 000 mapping campaign carried out in the framework of European-funded Mining Sector Support Project (MSSP) and presented in de Kock et al. (2009), Siegfried et al. (2009) and Thomas et al. (2009). The field data was used to constrain the interpretation of the following geophysical datasets.

- Regional airborne magnetics provided by the Geological Survey Department of Ghana, with a gridded resolution of $100 \mathrm{~m}$ and $200 \mathrm{~m}$, with a flight height of $70-80 \mathrm{~m}$.

- Regional airborne radiometrics provided by the Geological Survey Department of Ghana, with a gridded resolution of $100 \mathrm{~m}$ and $200 \mathrm{~m}$, with a flight height of $70-80 \mathrm{~m}$.

- Regional airborne electromagnetics provided by the Geological Survey Department of Ghana, with a gridded resolution of $100 \mathrm{~m}$, with a flight height of 70-80m.

- High resolution airborne magnetics provided by Azumah resources, with a gridded resolution of $25 \mathrm{~m}$, with a flight height of $40 \mathrm{~m}$.

- High resolution airborne radiometrics provided by Azumah resources, with a gridded resolution of $25 \mathrm{~m}$, with a flight height of $40 \mathrm{~m}$.

\subsection{Main lithologies}

The geological map presented in Figure 3 shows the representative lithologies of the study area. They are presented below and in Table 1, along with their respective magnetic susceptibilities, radiometric and electromagnetic signals.

\section{Voltaian cover}

Neoproterozoic sediments of the Volta basin (Affaton et al., 1980) are discordant on Paleoproterozoic formations. The basal sediments at the discordant contact generally consist of sandstone and fine grained arkoses displaying ubiquitous cross-beds. 


\section{Granitoids}

Five major types of granitoids are distinguished in the study area based on their petrography, geophysical properties, and the relative chronology of their emplacement. In a chronological order, they are:

(1) G1. Calc-alkaline tonalite-trondhjemite-granodiorite intrusions, equivalent to ME1 in Baratoux et al. (2011), and Metelka et al. (2011). They are generally amphibole- and biotite-bearing, and K-feldspar is absent. Their magnetic susceptibility is variable and covers a large range of values $\left(0.05-10 \times 10^{-3} \mathrm{SI}\right.$, Table 1). The TTGs generally show a penetrative gneissic metamorphic banding and are frequently migmatitic.

(2) G2. Calc-alkaline granodiorite, monzogranite and monzodiorite intrusions (G2). They contain biotite and/or amphibole, as well as K-feldspar. They are usually melanocratic due to high proportions of ferromagnesian minerals. Magnetic susceptibility is moderate to low $\left(0.10-0.30 \times 10^{-3} \mathrm{SI}\right)$ and gamma ray emissions are dominated by $\mathrm{K}$ (Table1). Deformation intensity is variable and is reflected by a preferential mineral orientation. No gneissic fabrics are found. The plutons are sigmoidal or elongated. (3) G3. Calc-alkaline granodiorite plutons bearing biotite-, amphibole- titanite- and small proportions of K-feldspar. They share petrological similarities with G2 granitoids, but they are distinguished on the field by a coarse grain size (centimetric grains), a high magnetic susceptibility (1-55 $\left.\times 10^{-3} \mathrm{SI}\right)$ and depletion in U-Th-K reflected by a dark radiometric signal (Table1). Strain is generally low and increases towards shear zones or pluton margins. This type of intrusive is represented by a large batholith in the Koudougou-Tumu granitoid domain.

(4) G4. Leucocratic K-feldspar- biotite-granites, possibly equivalent to ME2 of Baratoux et al. (2011) and Metelka et al. (2011). They are spatially associated to the interference zone between the Wa-Lawra and Bole-Nangodi shear zones, in the Bole-Bulenga terrain and the Wa-Lawra granitoid domain. They form aligned, elongated plutons, intercalated within the migmatitic 'composite gneisses' or intrusive in metasediments. Their magnetic susceptibility is very low $\left(<0.01-0.15 \times 10^{-3} \mathrm{SI}\right)$, and they have high $\mathrm{K}$ and Th emissions.

(5) G5. Potassic porphyric granites, sometimes metaluminous, and sporadic syenites, equivalent of ME3 of Baratoux et al. (2011) and Metelka et al. (2011), form circular plutons. Amphibole is scarce or absent. They are generally undeformed or internally display localised anastomosing shear bands. The magnetic 
susceptibility range is bimodal, and gamma ray emissions reveal a strong enrichment in all incompatible elements.

\section{Mafic orthogneiss}

This rock is a melanocratic, hornblende-rich tonalitic gneiss, generally migmatitic. It is found across the study area as pluri-kilometric bodies or as multiple slivers a few $100 \mathrm{~m}$ wide, elongated along shear zones at the margins of the Bole-Bulenga terrain. It represents a high-strain marker unit. This lithology presents a variable, but generally high magnetic susceptibility (up to $10 \times 10^{-3} \mathrm{SI}$ ).

\section{Gabbro/meta-gabbro}

Hornblende-bearing gabbros, gabbronorites and minor pyroxenites form elliptical bodies up to 10km long in the Maluwe basin. The Koudoukou-Tumu granitoid domain also contains gabbro plutons with irregular shapes. They are characterised by a moderate magnetic susceptibility $\left(0.2-2 \times 10^{-3} \mathrm{SI}\right)$ and depletion in incompatible elements.

\section{Arkose/conglomerate}

A relatively small $(20 x 8 \mathrm{~km})$ detrital sedimentary basin is located on the southeastern margin of the Julie belt, along the contact with the Bole-Bulenga terrain. It contains coarse-grained sediments, immature quartzites, arkoses and conglomerates, metamorphosed under low-grade conditions. The lithology resembles Tarkwaian sediments (which represent the youngest formation of the Paleoproterozoic volcano-sedimentary belts of West Africa) and is hereafter referred to as Tarkwaiantype sediments. They display cross-beds underlined by thin magnetite-rich strata. The magnetic susceptibility of the rock is therefore heterogeneous and locally very high. The radiometric signal indicates moderate $\mathrm{K}$ and high Th emissions.

\section{Manganesiferous cherts}


Mn-rich silicic sediments are found in the Nangodi belt and in the Maluwe basin, along the transition zone with the Bole-Bulenga terrain. They form dark, massive sediments with a low magnetic susceptibility $\left(<1 \times 10^{-3} \mathrm{SI}\right)$ and depletion in incompatible elements.

\section{Al-rich quartzite}

This lithology of limited extent forms prominent ridges in the southern Bole-Bulenga terrain and along the contact with the Maluwe basin. It is a unit a few hundred metres wide and discontinuous segments may be followed along strike for a few km. Its mineralogy essentially consists of quartz and kyanite.

\section{Rhyolite/meta-rhyolite}

Rhyolites and felsic pyroclastites are found in the Maluwe basin, where they form elongated units of a few hundred km wide. They frequently contain flattened bombs and clasts, and show an enrichment in incompatible elements, particularly Th and K relative to U. Magnetic susceptibility is variable but mostly low $\left(<0.2 \times 10^{-3} \mathrm{SI}\right)$.

\section{Andesite/meta-andesite}

Intermediate calc-alkaline lavas and pyroclastites are intercalated with phyllitic sediments and volcanosediments in the Maluwe basin, in the Wa-Lawra and Nangodi belts. Some units are undeformed and preserve magmatic fabrics, while others are intensely sheared. They have a low $\left(0.3-0.4 \times 10^{-3} \mathrm{SI}\right)$ magnetic susceptibility and their radiometric signal reveals a relative enrichment in U.

\section{Basalt/meta-basalt}

Basalts metamorphosed under lower-greenschist to amphibolite-facies conditions form rock units folded and elongated parallel to the strike of major structures in the Wa-Lawra, Julie and Nangodi belts. Airborne geophysical data reveals high-magnetic basaltic lava layers depleted in incompatible elements.

\section{Volcanosedimentary schist}


The lithology mapped as volcanosedimentary schist (Fig. 2) encompasses a variety of rocks including greywacke, shales and felsic to intermediate volcano-sediments. They record a low-grade metamorphic overprint in sub-greenschist to amphibolite-facies conditions. They contain metamorphic assemblages which include quartz-feldspar-chlorite-white mica or quartz-feldspar-chlorite-actinolite. The volcanosedimentary schist represents the dominant lithology of the Maluwe basin, the Nangodi and Wa-Lawra belts. It generally displays homogeneous low magnetic susceptibility values $\left(0.05-0.55 \times 10^{-3} \mathrm{SI}\right)$, and $\mathrm{K}+\mathrm{Th}$ enrichment relative to $\mathrm{U}$.

\section{Paragneiss}

The Abulembire and Bole-Bulenga terrains contain abundant paragneiss derived from greywacke, volcano-sedimentary or pelitic protoliths. They witnessed amphibolite- to granulite-facies metamorphic conditions. They develop a gneissic texture defined by alternating quartz- and mica-rich beds, and sometimes display a migmatitic banding. Garnet is a common mineral, while staurolite or aluminosilicates are found in the most Al-rich layers. Magnetic susceptibility is low for this lithology $\left(<0.35 \times 10^{-3} \mathrm{SI}\right)$

\section{Composite gneiss}

Large proportions of the Abulembire and Bole-Bulenga terrains are formed by migmatitic ortho- and paragneisses intruded by varying proportions of granitic melts and two-mica pegmatite dikes. They together constitute a heterogeneous lithology termed "composite gneiss" and distinguished from the paragneiss based on its distinctive $\mathrm{K}+\mathrm{Th}$ relative enrichment (Table 1).

Table 1: Synthesis of the petrophysical properties and geophysical signatures of the lithologies represented on the geological map (Fig. 2). The magnetic image is the automatic gain control of the first vertical derivative of the negative of the Reduced to the Equator airborne magnetics. The radiometric imaged is draped over the shaded SRTM digital terrain model. The electromagnetic image represents the in-phase (IP3125) signal. Whole rock geochemical analyses were conducted by A.L.S. Mineral Laboratory, Sevilla, Spain. Data Olivier 


\section{4- Tectono-metamorphic history}

\section{1-Deformation sequence}

\section{D1: $N$-S directed shortening}

The low-grade lithologies of the Julie belt are affected by an early deformation event which generated E-W trending fabrics and structures. Early fabric trajectories in the KTGD migmatitic gneisses define an arcuate geometry oriented E-W. To the south-west of the Jirapa SZ, gneisses and volcanic rocks stretching west into Burkina Faso and Côte d'Ivoire have a strike that is consistently oblique relative to the orientation of the Wa-Lawra belt. Similar observations can be made in fabrics in high-grade orthoand paragneisses of the Abulembire terrain. In the Bole-Bulenga terrain, the early high-grade metamorphic banding is oriented approximately E-W and shows a variable transposition by later deformation. This early deformation is hereafter referred to as D1.

In the Maluwe basin, D1 is associated with a shallow-dipping penetrative cleavage, parallel to the stratigraphic layering (S0) of low-grade metasediments. In the Julie belt, the deformation generates kmscale, E-W striking folds in the basalts, volcano-sedimentary rocks and "Tarkwaian-type" detrital sediments. These rocks develop a shallowly- to steeply-dipping foliation S1, which carries reverse, top to the south kinematic indicators. In high-grade rocks, S1 is a shallowly to steeply-dipping gneissic foliation. It is parallel to a transposed stratigraphic layering (S0) in metasediments, and is defined by alternating parallel neosomes and paleosomes in migmatitic rocks (Fig. 3, a; c). S1 foliation is axial planar to F1 isoclinal and recumbent folds, and carries a strongly plunging mineral elongation lineation L1.

The Julie shear zone contains high strain amphibolites, schists and a sheared granitoid. The foliation dips $50-70^{\circ} \mathrm{N}$ and carries a stretching lineation plunging down-dip, towards higher grade rocks. The Julie SZ is interpreted as a thrust, consistent with N-S directed shortening D1. To the north-east of Bulenga town, the Bole-Nangodi shear zone brings in contact migmatitic amphibolites, ortho and 
paragneisses on top of chlorite schists of the Maluwe basin. This implies that the Bole-Nangodi shear zones probably formed as a reverse shear zone during D1, before later re-activation during subsequent deformation.

Field observations indicate that N-S directed shortening D1 causes folding and thrusting, generates metamorphic breaks across narrow high-strain zones, and is coincident with high-grade metamorphism and partial melting of the crust.

\section{D2: $N$-S directed extension.}

The north-dipping Bulenga shear zone forms the boundary between the Julie belt and the northern part of the Bole-Bulenga terrain. It consists of a high-strain granitoid gneiss, which separates a granodiorite pluton and Tarkwaian-type detrital sediments in the hanging-wall from migmatitic ortho- and paragneisses in the footwall. The gneiss has a moderate dip $\left(40-50^{\circ}\right)$ to the north, and the foliation carries a lineation plunging down-dip (L2, plunging to N020, Fig. 7, c), towards lower grade lithologies of the Julie Belt (Fig. 3, b, the arrow indicates the direction of increasing metamorphic grade). The Bulenga shear zone is interpreted as an extensional detachment. On the southern margin of the Bole-Bulenga terrain, at the contact with the Maluwe basin, the Bole shear zone dips $50-80^{\circ}$ to the south. It contains a high-strain mafic orthogneiss, which sometimes displays intense retrogression. The foliation planes carry a mineral stretching lineation plunging down dip (L2, plunging to N210-220, Fig. 7, c), towards the lower-grade volcano-sedimentary rocks of the Maluwe basin. It is also interpreted as an extensional shear zone. Therefore, the Bole-Bulenga terrain is separated along its northern and southern limits from lower-grade metamorphic terrains by structures dipping in opposite directions, consistent with a N-S directed extension, termed hereafter D2.

In the field, D2 does not develop a strong fabric away from the above-mentioned shear zones, and no overprinting relationships could be observed between D1 and D2 structures. Within the Bole-Bulenga terrain, shallow-dipping high-strain contacts between rock units may be attributed to D2. 

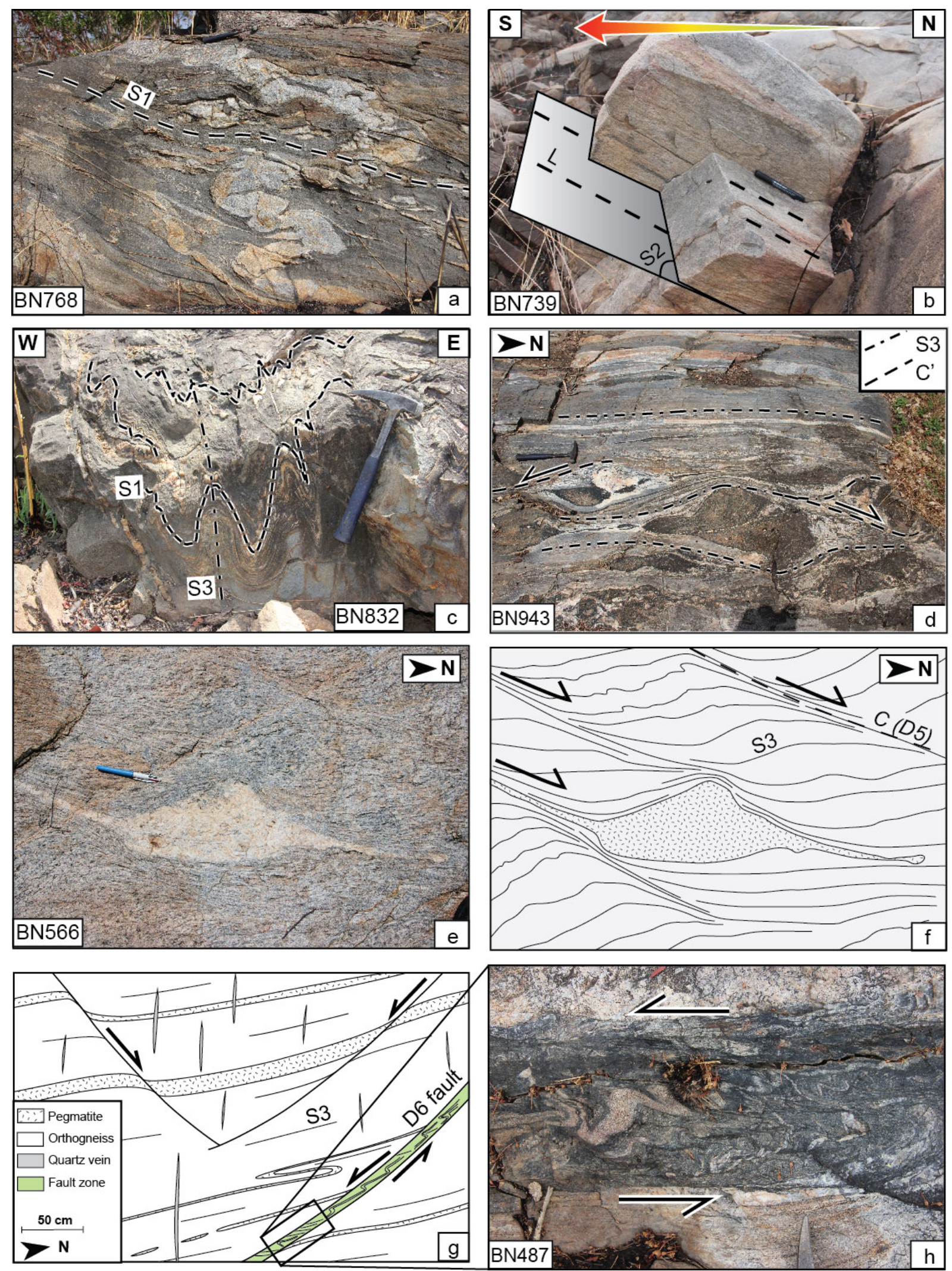

Figure 3: Field photographs of representative structures. See Fig. 5, 8 for outcrop locations. a) Paragneiss metatexite in the Bole-Bulenga terrain displaying a shallow-dipping foliation S1, axial planar to recumbent folds. b) High-strain orthogneiss in the Bulenga shear zone. The foliation dips 
moderately to the $N$ and carries a stretching lineation plunging down-dip. The arrow points towards increasing metamorphic grade. c) Ptygmatic folds in a migmatitic paragneiss transposing S1 parallel to a subvertical N-S cleavage S3. d) Migmatitic “composite” gneiss in a D3 (N-S) shear zone, containing flattened pyroxenite boudins bounded by symmetrical "extensional” (C') shear bands. e) Orthogneiss displaying a subvertical S3 fabric cross-cut by high-temperature dextral C'shear bands, characteristic of D5. An interpretative sketch is shown in f). g) Sketch of an orthogneiss outcrop showing the gneissic fabric offset by conjuguate strike-slip brittle faults, and associated quartz-tension gashes. $h$ ) Photograph of a detail from g) showing a sinistral strike-slip fault infilled by pseudotachylite. Features displayed in g) and h) are attributed to D6.

\section{D3: E-W directed shortening.}

Fabrics, structures and isograds formed during D1 and D2 are overprinted by deformation D3 consistent with E-W directed shortening (Fig. 3, c). D3 generates a sub-vertical schistose cleavage S3 which consistently strikes N020 (Fig. 7, c). Strain intensity is irregular and increases in the vicinity of subvertical high-strain zones oriented approximately N-S, where S1 and S2 are fully transposed parallel to S3. Kinematic indicators (fold and boudin geometry, Fig. 3, d) suggest a dominance of coaxial shearing in D3 shear zones. S3 bears a mineral stretching lineation L3 which is characterised by low to moderate pitch to the NNE or SSW (Fig. 7, c) across the study area.

D3 fabrics are intensely developed in the low-grade volcano-sedimentary and sedimentary formation of the Maluwe basin, the Nangodi and Wa-Lawra belts. The penetrative schistose cleavage S3 is axial planar to isoclinal folds F3, defined by the recrystallization of biotite, chlorite and white mica. In the Julie belt, D3 strain is weak and characterised by crenulation cleavages. A strong strain gradient is observed towards the eastern extent of the belt, as D1 folds and fabrics are increasingly transposed parallel to a D3 shear zone striking N020 (Fig. 5). In the high grade gneisses of the Bole-Bulenga terrain, S3 forms a penetrative foliation and is axial planar to isoclinal or ptygmatic folds F3 (Fig. 3, c). Locally, migmatitic paragneisses display leucosomes oriented parallel to S3 and accumulated in F3 fold hinges (Fig. 4). D3 deformation is associated to a medium- to high-grade metamorphic overprint. 
At a larger scale, D3 forms an alternation of sub-solidus amphibolite-facies rocks and of migmatitic, amphibolite- to granulite-facies gneisses, elongated parallel to a N-S structural trend and shear zones, and a repetition of lithologies is observed along E-W transects. These structures are further discussed in section 6.2.

D3 strain intensity gradually decreases to the south of the study area, in the south of the Maluwe basin and in the Abulembire terrain. Similarly, the KTGD seems to behave as a rigid bloc unaffected by D3, except along its margins.

\section{D4: ENE-WSW shortening and localized sinistral strike-slip shearing}

The late-stage tectonic evolution of the study area is characterized by a gradual shift from distributed strain across litho-tectonic domains to localized strain at terrain and lithological boundaries. This shift in tectonic regime is illustrated by the activation of the Jirapa and Jang shear zones as sub-vertical sinistral strike-slip shear zones. Leucosomes and granitic dikes in gneisses in the Jang shear zone are boudinaged and deformed as competent material, indicating sub-solidus deformation conditions. S-CC' fabrics develop around porphyroclasts, and ductile deformation in the Jang shear zone suggests relatively high-T conditions. The growth of chlorite, muscovite and biotite grains stretched in a subhorizontal lineation on foliation planes in the Jirapa shear zone indicates that deformation occurred under greenschist-facies conditions. The observation of early microstructures (e.g. symmetrical folds, moderately-plunging stretching lineations defined by amphibolite-facies metamorphic minerals) in rocks from the Jirapa and Jang shear zones suggests that these structures are inherited and formed prior to further re-activation and re-orientation in a strike-slip setting (i.e. they formed before or during D3).

\section{D5: E-W shortening and localized dextral strike-slip shearing}

A set of sub-vertical dextral strike slip shear zones develops in the Bole-Bulenga terrain and transects lithological contacts. In the gneisses, S3 is offset by dextral (C') shear bands (Fig. 3, e; f). Ductile fabrics indicate relatively high-T conditions for D5 deformation. The contact zone between the Maluwe basin 
and Bole-Bulenga terrain is dragged into the Bole-Nangodi shear zone, which is re-activated as a dextral shear zone. Lower-amphibolite- to greenschist-facies retrograde metamorphic overprints develop within this shear zone.

D6: E-W shortening, brittle deformation

Brittle structures consistent with an east-west shortening, such as E-W quartz tension gashes, sometimes chlorite, white mica or epidote-bearing, and conjugate brittle strike-slip faults cross-cut the previous structures (Fig. 3, f; g). This defines another deformation event: D6.

\section{D7: NE-SW shortening, brittle deformation}

Incompetent lithologies (e.g. shales, chlorite schists, etc) occasionally develop a cross-cutting subvertical crenulation cleavage, which represent the latest fabric observed in the study area. 

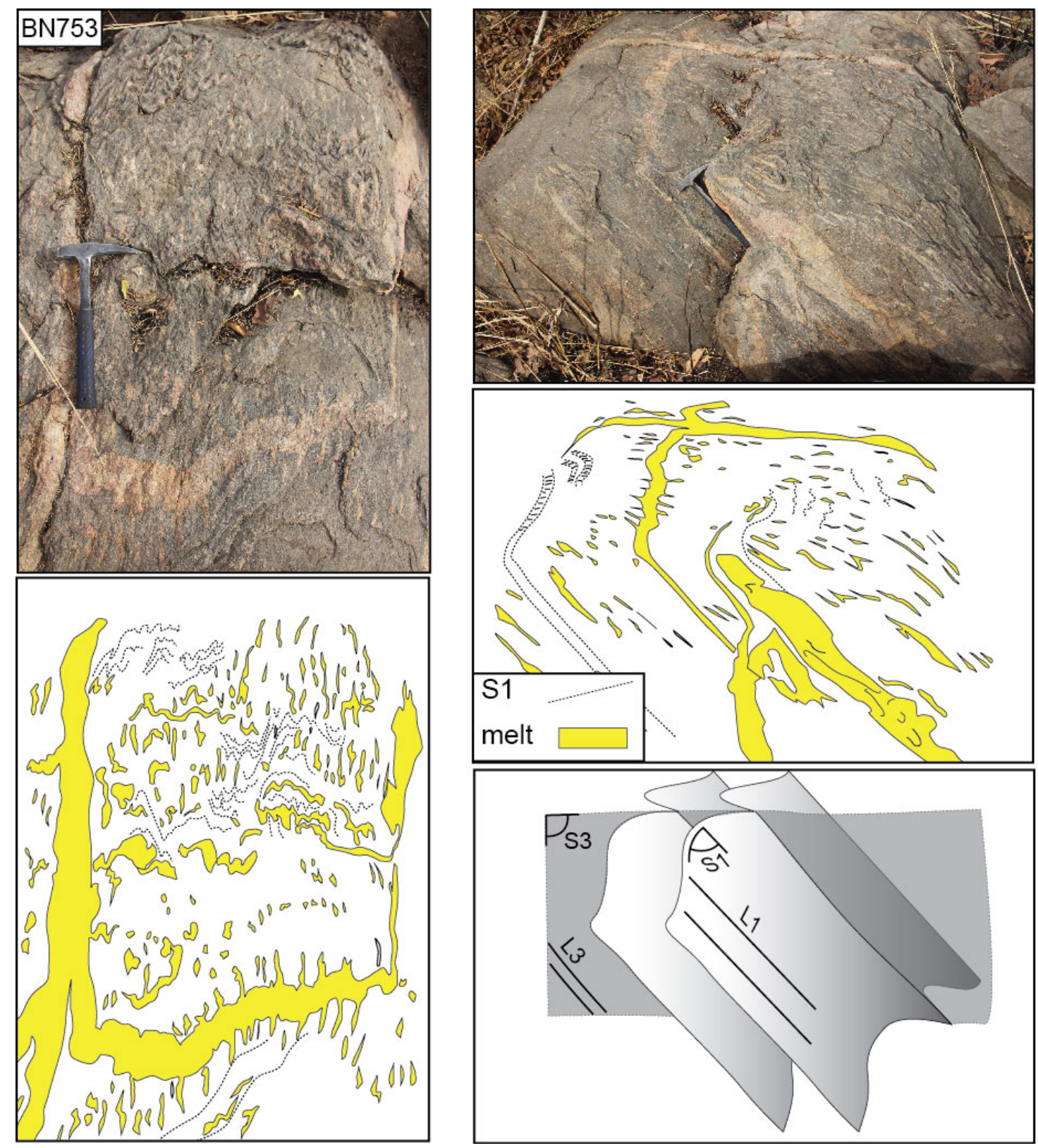

Figure 4: Photographs and interpretative sketches of a migmatitic paragneiss from the Bole-Bulenga terrain. Foliation S1 is parallel to stratigraphic horizons and dips moderately to the south. It is overprinted by a sub-vertical schistose cleavage S3 axial-planar to tight folds attributed to D3. Melting is evidenced by pinkish granitic leucosomes formed in more fusible (pelitic) layers Leucosomes parallel to S1 are folded and are transposed parallel to axial surfaces of F3 folds, indicating that the rock melted during D3. L1 and L3 have identical orientations.

\section{2-Metamorphic history}


A regional metamorphic study based on petrological and geochronological constraints is presented in Block et al., XXX. Eclogite-facies relics are sporadically preserved as cores of zoned garnet porphyroblasts equilibrated at high pressures in paragneisses of the Bole-Bulenga and Abulembire terrains. The garnet cores contain oriented inclusion trails which are oblique to S1. They record P-T conditions of $10-14 \mathrm{kbar}, 520-600^{\circ} \mathrm{C}$, which correspond to a low $\left(\sim 15^{\circ} \mathrm{C} / \mathrm{km}\right)$ apparent geothermal gradient. The foliation S1 hosts amphibolite- to granulite-facies assemblages in high-grade rocks of the KTGD, the Bole-Bulenga and Abulembire terrains. L1 is defined by the stretching of hornblende, biotite, or kyanite in favourable lithologies. The high-grade metamorphic assemblages include biotite + garnet + kyanite + plagioclase + quartz + melt, and hornblende + garnet + clinopyroxene + plagioclase + quartz + melt in metapelites and metabasic rocks respectively. Granulite-facies rocks reveal a clockwise pressure-temperature-time (P-T-t) path characterised by melting at pressures above 10 kbar, followed by decompression and heating to peak temperatures of $800^{\circ} \mathrm{C}$ at $5-8 \mathrm{kbar}$, which fit a $30^{\circ} \mathrm{C} / \mathrm{km}$ apparent geotherm. In situ U-Pb dating of monazite constrains melting in a migmatitic paragneiss of the BoleBulenga terrain (sample BN 43) at $2137 \pm 8$ Ma (Block et al., XXX).

The sub-vertical, overprinting cleavage S3 carries high-grade metamorphic assemblages identical to those borne by the S1 fabric, indicating that it developed under similar P-T conditions. In the interference zone within the Bole-Bulenga terrain, a generation of leucosomes overgrows the S1 metamorphic banding. At outcrop scale, magma segregated in S1-parallel leucosomes migrates and is engulfed in low-stress zones, pressure shadow-zones and syn-D3 shear bands (Fig 3, d). Figure 4 shows a migmatitic paragneiss (sample BN753) with a shallow south-dipping foliation S1, parallel to a transposed sedimentary layering S0, recognisable by the alternation of layers of fusible and refractory compositions. S1 is overprinted by the subvertical cleavage S3, which is axial-planar to tight folds F3. Melt is collected in F3 axial surfaces and transposed parallel to S3 (Vernon \& Paterson, 2001). This observation provides evidence that conditions for partial melting were met during D3.

Late-kinematic subhedral staurolite is found partly overgrowing S3 and aligned parallel to the mineral stretching lineation L3, particularly in D3 shear zones. This suggests amphibolite-facies retrograde metamorphism at a late stage of D3. This metamorphic overprint affects eclogite- and granulite-facies 
rocks, and is characterised by conditions of $7-10 \mathrm{kbar}$ at $550-680^{\circ} \mathrm{C}$, which match a $20-25^{\circ} \mathrm{C} / \mathrm{km}$ apparent geotherm. The timing of amphibolite-facies metamorphism in the Abulembire and BoleBulenga terrains was constrained by in-situ U-Pb dating of monazite grains at $2131 \pm 6 \mathrm{Ma}$ (sample BN 436) and $2127 \pm 7 \mathrm{Ma}$ (sample BN 47) respectively (Block et al., XXX).

Replacement of garnet, aluminosilicates and biotite by chlorite, epidote and white mica, or of hornblende by epidote and green amphibole, is observed along D4 and D5 shear structures, which must have acted as late-stage fluid pathways. Further retrograde evolution is evidenced by quartz-chlorite, quartz-white mica and quartz-epidote veins, and by brittle faults infilled by chlorite.

\section{3-Structural-metamorphic map}

The structural and metamorphic data collected in the field and described above is presented in Figure 5. It displays the trajectories of foliation S1, superimposed on the map of the distribution of metamorphic facies. S3 is also shown in lithologies where it forms the earliest fabric, i.e. in syn-D3 plutons. As in Figure 2, the shear zones are colour-coded to indicate the deformation phase under which they formed or were last-activated. This map illustrates that:

- The early fabric S1 is preserved away from the prominent N-S and NE-SW high-strain zones and from the interference zone between the Jirapa and Bole-Nangodi shear zones. It is distributed across all tectono-metamorphic terrains, and its strike varies from ENE to WNW. Isograds (e.g. melt in isograd) and metamorphic breaks are parallel to S1. They are formed by syn-D1 shear zones which terminate on younger structures. Syn-D2 structures have similar orientations and form terrain boundaries. They may be inherited from D1.

- S1 is transposed locally due to east-west shortening, in the vicinity of younger shear zones, and in particular in the interference zone between the Jirapa and Bole-Nangodi shear zones. Syn-D3 shear zones also generate metamorphic breaks or offset pre-existing ones. Isograds and tectonic contacts formed during D1/D2 are folded parallel to a NNE direction and transposed parallel to syn-D3 shear zones. 


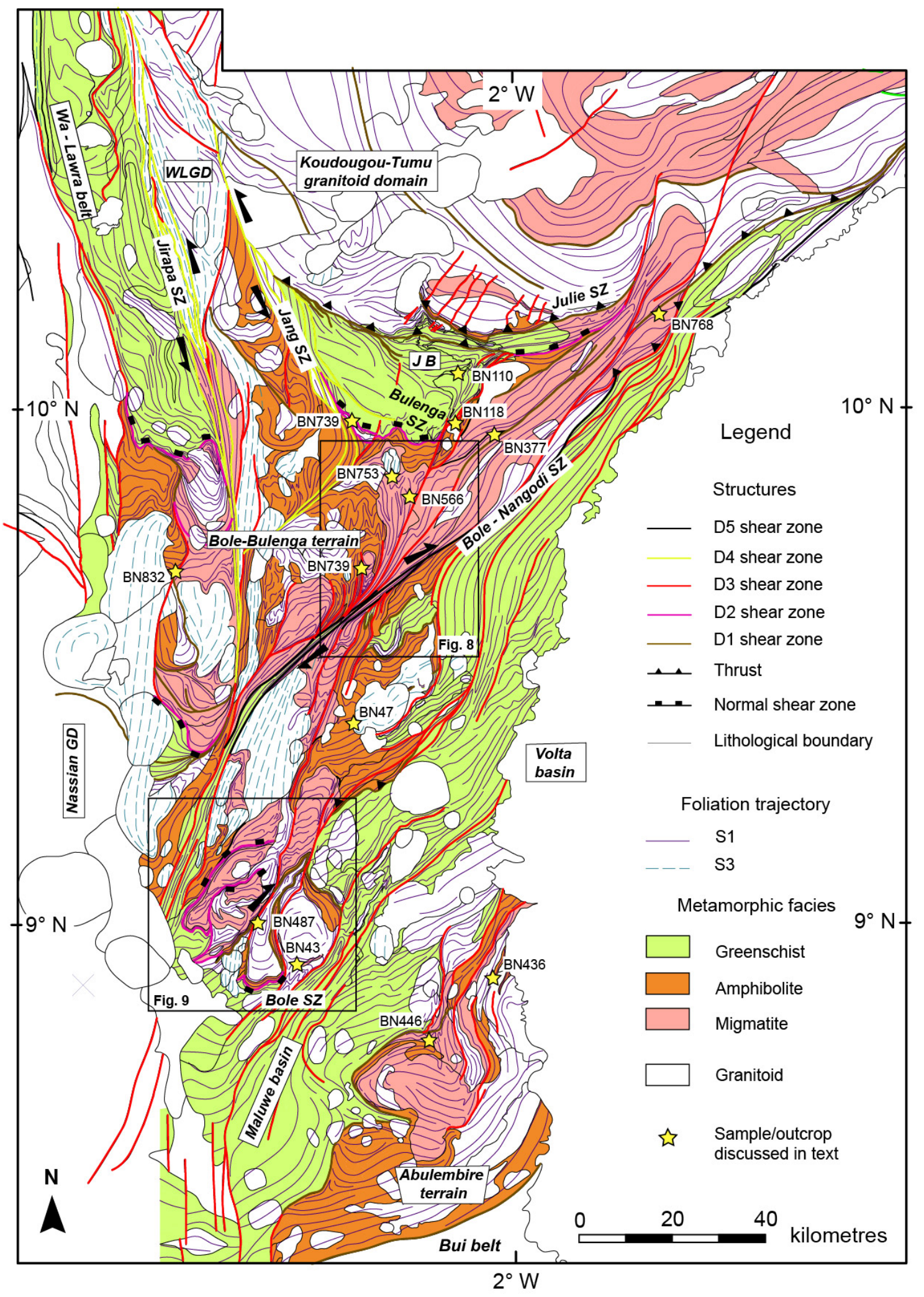

Figure 5. Structural and metamorphic map of the study area. For clarity, foliation trajectory S3 is only represented in lithologies where it is the earliest tectonic fabric (e.g. syn-D3 granitoids). Spacing between trajectory lines is inversely proportional to strain intensity. 


\section{5- Geochronology}

\section{1- Method and sample description}

$\mathrm{U}-\mathrm{Pb}$ dating was carried out on zircon and monazite grains in order to constrain the timing of deformation. A first set of analyses was carried out on zircons included in epoxy mounts for samples BN110, BN377, BN446 and BN753 using LA-ICP-MS at Montpellier. A second set of analyses was performed in-situ on a polished thin section of sample BN 118, using laser ablation - inductively coupled plasma - sector field - mass spectrometry (LA-ICP(SF)-MS) at Goethe University Frankfurt. Methodological details are provided in the appendix.

\section{- $\quad$ Sample BN 118}

Sample BN 118 is a staurolite-bearing paragneiss within a D3 shear zone, which separates the Tarkwaian-like sediments of the Julie belt, to the west, from higher-grade paragneiss of the BoleBulenga terrain, to the east. Fabrics in the shear zone are transposed parallel to S3, which forms a penetrative metamorphic banding. The rock has a quartz-biotite-plagioclase-ilmenite matrix, and contains millimetric garnet and syn-kinematic staurolite porphyroblasts. The porphyroblasts are elongated parallel to the L3 stretching lineation. Monazite grains 15-60 $\mu \mathrm{m}$ long and devoid from chemical zoning are deformed and aligned parallel to matrix minerals.

\section{- Sample BN110}

Sample BN110 is a volcano-sedimentary rock from a F1 fold limb in the "Tarkwaian-like" sedimentary basin lain in the hanging-wall of the extensional Bulenga shear zone. It is a silicic rock containing quartz phenocrystals, sodic plagioclase, K-feldspar in a matrix of oriented white micas. The rock is probably derived mainly from felsic volcanic products mixed with clastic material. The sample contains abundant zircons that form a homogeneous population in terms of size, colour and morphology. Observed in backscattered electron microscopy the grains have euhedral shapes without rounding of the terminations 
and euhedral oscillatory zoning. These characteristics point to a local, magmatic origin and are inconsistent with transport of sedimentary material over a long distance.

- $\quad$ Sample BN377

Sample BN 377 originates from an outcrop of migmatitic "composite gneiss" in the northeastern BoleBulenga terrain. The rock comprises a granodiorite gneiss intercalated with paragneiss layers, pyroxenite lenses, and develops a foliation and a migmatitic banding S1. Secondary grain recrystallization defines later fabric S3, parallel to granitic dikes. The sample is a leucocratic segregate $10-20 \mathrm{~cm}$ thick separated from the paleosome by biotite selvedges elongated parallel to S1. Zircon grains display oscillatory zoning patterns and subhedral shapes, suggesting a magmatic origin and possible resorbtion during metamorphism. Some grains show complex internal structures (Fig. 6, a). They contain inherited cores rimmed by domains with oscillatory zoning. The zoning pattern is sometimes erased in outer rim domains, suggesting secondary recrystallisation of magmatic zircon.

\section{- $\quad$ Sample BN 446}

This sample originates from a stromatic migmatitic paragneiss containing abundant biotite and garnet in the Abulembire terrain. Thin $(<1 \mathrm{~cm})$ leucosomes are parallel to the S1 cleavage and are transposed to S3 by axial planar ptygmatic folds. They are connected to $2-10 \mathrm{~cm}$ large granitic veins and dikes which cross-cut the fabrics. Zircon grains have similar euhedral shapes, morphologies and colours, and display oscillatory zoning patterns consistent with a magmatic origin. They are rimmed by thin $(<10 \mu \mathrm{m})$ anhedral domains, which correspond to metamorphic overgrowths.

\section{- Sample BN 753}

Leucosome segregates were sampled from the outcrop of migmatitic paragneiss presented in Fig. 5, and which is located in the northern Bole-Bulenga terrain. The leucosomes are transposed parallel to F3 fold axial surfaces. Most zircon grains are euhedral and translucent, with fine oscillatory zoning patterns, suggesting crystallisation from the magma. Inherited grains occur as cores in magmatic grains, or are 
rimmed by anhedral overgrowths (Fig. 6, b). The metamorphic overgrowths display a complex zonation which may represent diffusion fronts.

\section{2- Results}

Results are presented in Figure 6 and Table 2.

\section{- $\quad$ Sample BN 118}

Seventeen U-Pb-Th spot analyses were carried out on eight elongated monazite grains located in the matrix (Fig. 6, c). Out of these, twelve analyses from seven monazite grains yield a Concordia age of $2122.9 \pm$ 8.3 Ma (MSWD $=0.41$ PROB $?)$. This age is interpreted as the age of crystallisation of metamorphic monazite in sample BN 118, and is a maximum age for D3 deformation reflected by monazite orientation.

\section{- $\quad$ Sample BN110}

The twenty four spot analyses out of as many zircon grains define a cluster of sub-concordant analyses which yields a ${ }^{207} \mathrm{~Pb} /{ }^{206} \mathrm{~Pb}$ weighted mean age of $2129 \pm 7 \mathrm{Ma}(\mathrm{MSWD}=1.0$, Fig. 6, d). Since the grains have simple internal structures, and define a single age population, this age is interpreted as dating the age of the volcanic material eroded and deposited with the detrital material. It is tentatively proposed that 2129 Ma closely approximates the deposition age of the sedimentary material. 

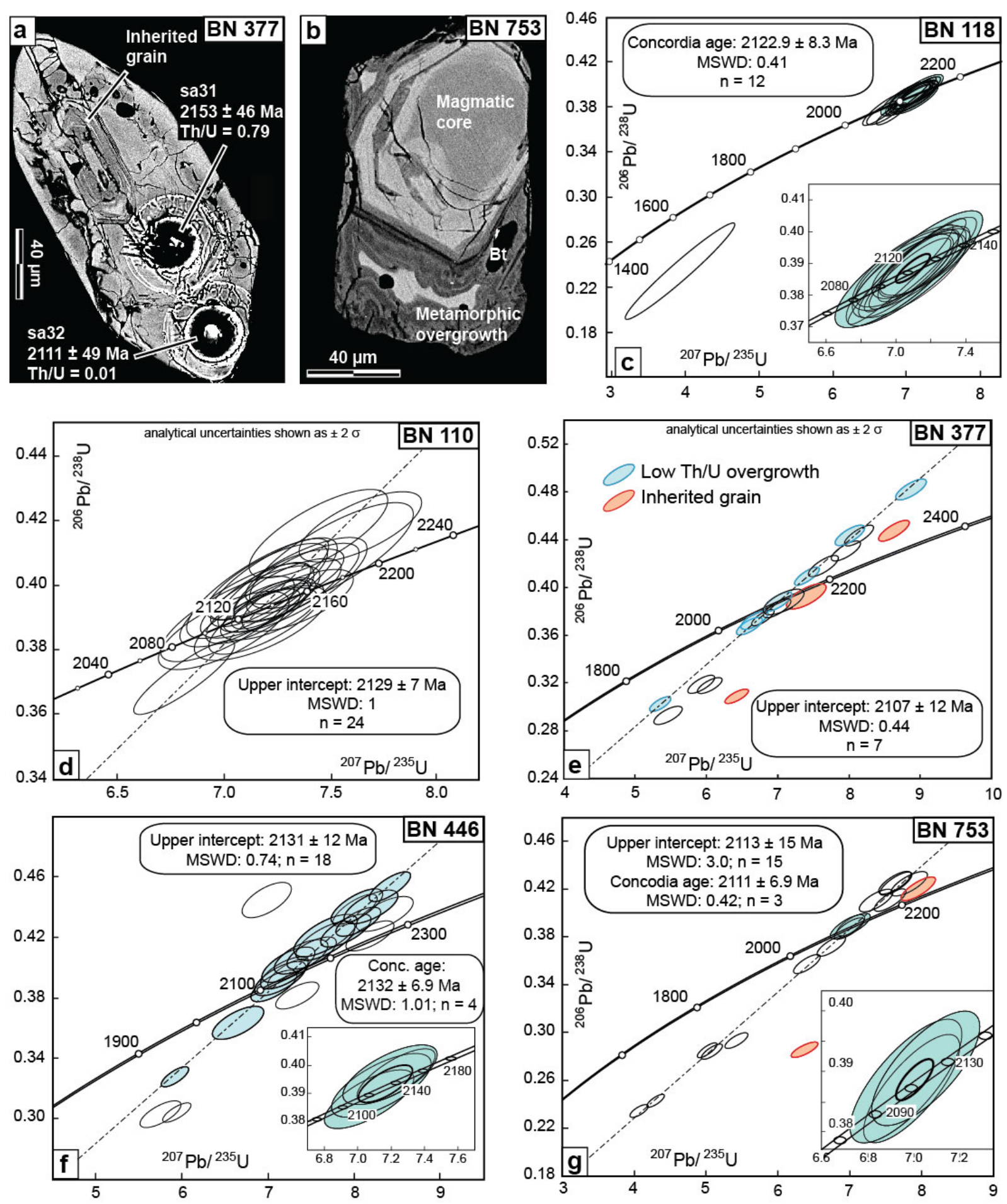

Figure 6. (a): Zircon grain from sample BN377 displaying an oscillatory zoning pattern. It contains an inherited grain and is rimmed by a recrystallized domain devoid of zoning, which yields a younger $\mathrm{Pb} / \mathrm{Pb}$ age, associated to a lower Th/U ratio. (b) Zircon grain from sample BN753 with an oscillatory zoning pattern, overgrown by a metamorphic rim containing biotite inclusions. (c): Results of $U-P b$ dating by LA-ICP-(SF)-MS of monazite of sample BN118. (d-g): Results of U-Pb dating of zircon of 
samples BN110, BN377, BN446 and BN753, presented in Concordia diagrams. Errors include decay constant uncertainties. Red ellipses show analyses of inherited grains, blue ellipses represent analyses of metamorphic zircon overgrowths, and black shaded ellipses show analyses used for crystallisation age calculation.

- Sample BN377

Twenty U-Th-Pb spot analyses were carried out on selected domains of sixteen zircon grains. Sixteen spot analyses from fourteen zircon grains have consistent individual ${ }^{207} \mathrm{~Pb}-{ }^{206} \mathrm{~Pb}$ ages (Fig 6, e). Three discordant analyses from zircon cores (\#3-2, 10-1 and 11-1) yield ${ }^{207} \mathrm{~Pb}-{ }^{206} \mathrm{~Pb}$ ages older than $2200 \mathrm{Ma}$,

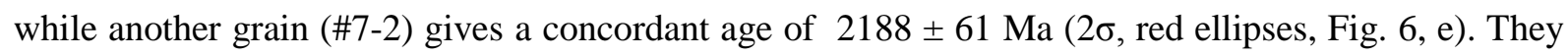
are interpreted as being inherited from the protolith. The other analyses define a limited range of overlapping ages, and data points spread along a regression line providing an upper-intercept age of $2121 \pm 18$ Ma (MSWD = 3.0). However, these analyses can be broken out into two groups based on textural criteria. Eight analyses in inner domains displaying oscillatory zoning patterns and high $(>0.4)$ Th/U ratios (e.g. \#14-1, black ellipses) plot along a regression line with an upper-intercept age of 2136.7 \pm 11 Ma (MSWD $=1.8$, not shown), interpreted as the age of zircon crystallisation from magma generated during migmatisation. Eight other analyses from recrystallized rims characterised by low $\mathrm{Th} / \mathrm{U}$ ratios (<0.02) (e.g. \#8-2, blue ellipses, Fig 6, a; e) define a younger upper-intercept age of $2107 \pm$ $12 \mathrm{Ma}(\mathrm{MSWD}=0.48)$, suggesting recrystallization of magmatic grains during a high-T metamorphism.

\section{- Sample BN446}

Twenty four U-Pb-Th spot analyses were obtained from as many zircon grains. All spots were aimed at the domains displaying euhedral oscillatory zoning, because the overgrowths are too thin to be analysed. Seventeen analyses yielded identical ${ }^{207} \mathrm{~Pb}-{ }^{206} \mathrm{~Pb}$ ages and define an upper intercept age of $2131.3 \pm 12$ Ma (MSWD $=0.74)$, which is within error of a Concordia age of $2132 \pm 6.9 \mathrm{Ma}(\mathrm{MSWD}=1.01$ Prob $=0.32, \mathrm{n}=4$, Fig. 6 , f). Other grains provide older ${ }^{207} \mathrm{~Pb}^{206} \mathrm{~Pb}$ ages, including two concordant analyses at ca. 2200 and 2240 Ma ages (\#22-1 and 24-1 respectively). The $2132 \pm 6.9$ Ma Concordia age is interpreted to date crystallisation of the volcanic protolith of the migmatitic gneiss, and therefore 
provides a maximal age for metamorphism, while older ages date the crystallisation of inherited cores rimmed by younger domains. This age is identical to the age of zircons in the volcanoclastic sample BN110.

- $\quad$ Sample BN753

Nineteen U-Pb-Th LA-ICP-MS spot analyses were obtained out of sixteen zircon grains (Fig. 6, g). Out of these, fifteen analyses from thirteen euhedral (magmatic) grains have consistent ${ }^{207} \mathrm{~Pb}-{ }^{206} \mathrm{~Pb}$ ages and lay on a regression line yielding an upper intercept age of $2113 \pm 15$ Ma (MSWD $=3.0$ ). A cluster of

three concordant analyses provides an identical Concordia age of $2111 \pm 6.9$ Ma (MSWD $=0.42$, Probability $=0.52$. Four analyses from three zircon grains yield older ages. Analyses \#10-1 and 10-2 plot high above the Concordia curve (not shown in Fig. 6) and together define a ${ }^{207} \mathrm{~Pb} /{ }^{206} \mathrm{~Pb}$ weighted mean age of $2244 \pm 38$ Ma (MSWD = 0.42). Analyses \#1-1 and 8-1 respectively have concordant 2192 \pm 49 Ma a discordant $2475 \pm 47$ Ma ages $(2 \sigma)$ suggesting the occurrence of early Paleoproterozoic-late Archean components in the source region of the detritus. The $2111 \pm 6.9 \mathrm{Ma}$ age is interpreted to date zircon crystallisation from the melt, while older ages reflect the ages of clastic materials which were eroded and deposited to form the paragneiss.

\section{Discussion}

\section{1-Geochronological constraints on the tectonic evolution.}

We recognise fabrics in high-grade gneisses attributed to D1 (N-S shortening) and D3 (E-W shortening) bearing similar metamorphic assemblages, and underlined by the orientation of foliation-parallel leucosomes in migmatites. This suggests that both deformations occurred under similar metamorphic conditions, while the crust was partially molten. Deformation, metamorphism and partial melting affect a lithosphere in a state of thermo-mechanical disequilibrium (England and Thompson, 1984). This situation may be interrupted due to isostatic and thermal re-equilibration, or it may be maintained through time in a steady state by long-lived geological processes (Willett and Brandon, 2002). In both cases, a given volume of rock is not expected to remain at constant P-T conditions for long periods, and significant changes in metamorphic conditions are expected over time scales of 1-10 Ma (e.g. Rubatto 
and Hermann, 2001 for modern orogenic belts; Collins et al., 2004; Millonig et al., 2010 for Paleoproterozoic orogenic belts). Fabrics formed in similar metamorphic conditions are therefore likely to be nearly contemporaneous. In north-western Ghana, field observations do not provide any evidence for an interruption of tectonic activity between D1 and D3. Both deformations may have occured within a short period of time, and may represent a continuous evolution rather than two discrete events. This hypothesis is supported by geochronological data (Fig. 7, a). Partial melting associated with D1 fabrics in sample BN 377 is dated at $2136.7 \pm 11 \mathrm{Ma}$, while metamorphism of sample BN446 is constrained to be younger than $2132 \pm 6.9$. This age is identical within errors to the $2137 \pm 8 \mathrm{Ma}, 2131 \pm 6 \mathrm{Ma}$ and 2127 \pm 7 Ma ages of monazite in samples BN 43, BN 436 and BN 47 respectively (Block et al., XXX). Furthermore, metagreywacke in the Abulembire terrain (sample BN446) and "Tarkwaian-type" sediments in the Julie belt (sample BN110), contain volcanic material (sample BN 110) with crystallisation ages of $2132 \pm 6.9$ and $2129 \pm 7$ Ma respectively, which witnessed D1 deformation and metamorphism. The sediments must have been deposited in syn-tectonic basins formed during ongoing shortening. These ages therefore provides a minimum age for the end of D1 (Fig. 7). Granites intrusive in the Bole-Bulenga and Maluwe terrains (G4 in Fig. 2) with ages ranging from $2122 \pm 6$ Ma to 2118 \pm 3 Ma (De Kock et al., 2011), are unaffected by D1 and variably develop D3 fabrics, providing a minimum age for the end of D1 and for the beginning of D3.

The $2122.9 \pm$ 8.3 Ma age obtained from monazite in sample BN 118 provides a maximum age for the activity of a D3 shear zone and associated amphibolite-facies metamorphism, while syn-D3 melting in sample BN 753 is dated at $2111 \pm 6.9$ Ma, consistent with the $2107 \pm 12$ Ma metamorphic zircon overgrowths in sample BN377. An undeformed granite in the Wa-Lawra belt with a formation age of $2104 \pm 1$ Ma (Agyei Duodu et al., 2009) defines a minimal age for the end of D3. Geochronological data show that the exhumed lower crust recorded anatectic conditions maintained from $2137 \pm 8$ to ca. $2111 \pm 6.9$ Ma (Fig. 7, a). 


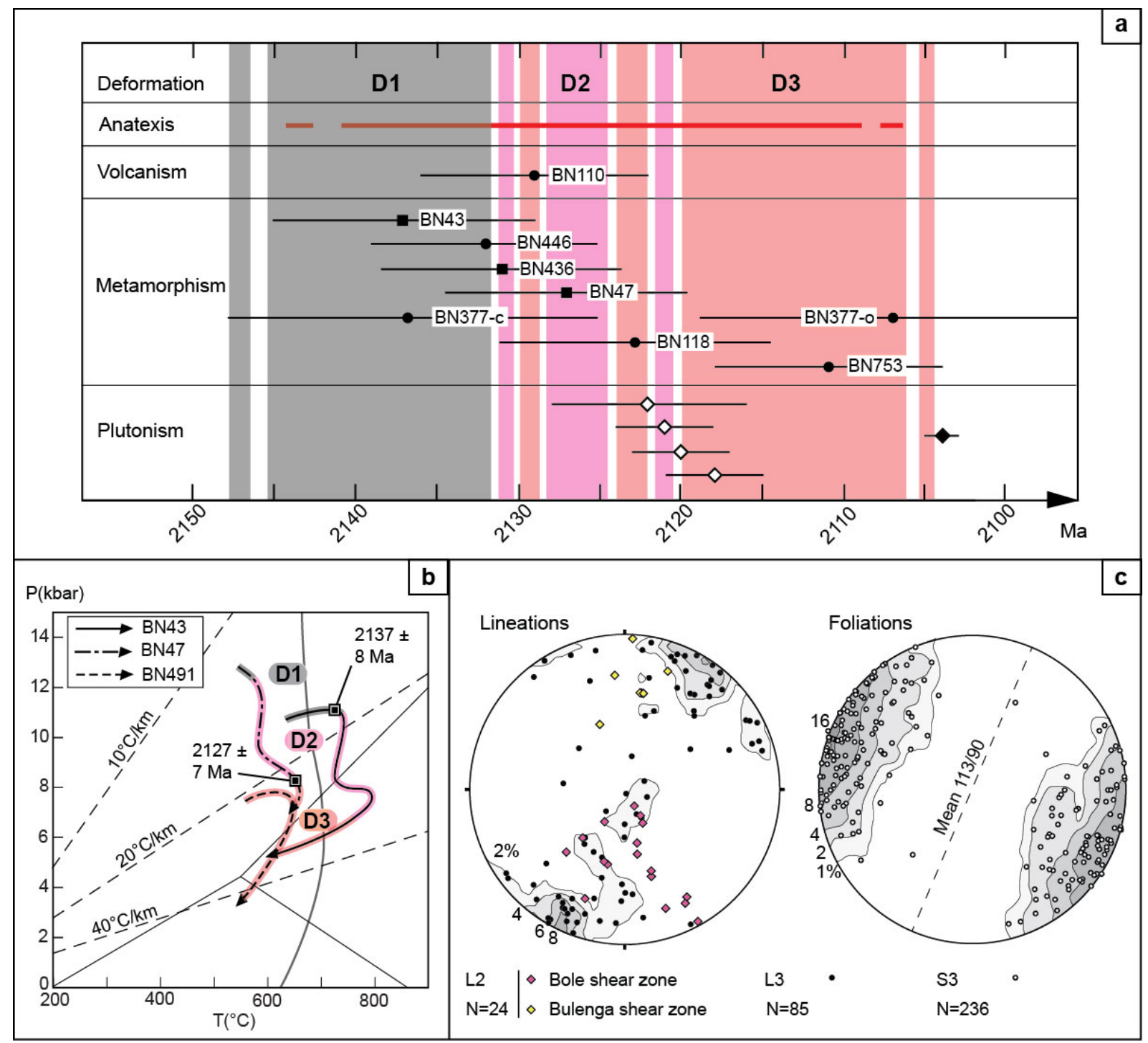

Figure 7. (a) - Summary of geochronological constraints on the timing of deformation. Black circles : this study, black squares : Block et al., XXX; white diamonds: syn-D3 granite crystallisation age from De Kock et al. (2011); black diamond: undeformed granite (Agyei Duodu et al., 2009). Data provide evidence for overlapping deformation events. (b) - Clockwise P-T-t-D paths followed by rocks of the Bole-Bulenga terrain with age constraints on granulite and amphibolite-facies metamorphic assemblages (Block et al., XXX). (c) - Stereograms built using the program Stereonet 7. Left: L2 lineations in the Bole (pink diamonds) and Bulenga (yellow diamonds) extensional shear zones, plotted with L3 lineations (black circles) and corresponding density contours. Right: S3 metamorphic foliation, density contours and mean plane. 
Deformations D1 and D3 are constrained by overlapping ages, pointing to a possible continuous evolution from one strain field to the other (Fig. 7, a). Although no overprinting relationships were found between D1 and D2 structures, we consider that extension affected a previously thickened crustal pile (see next section). This implies that extensional deformation D2 must occur in the bracket 21292111 Ma. The youngest granite intrusion constrained by U-Pb ages in the study area is dated at $2095 \pm$ 1 Ma (black diamond in Fig. 7. a, Agyei Duodu et al., 2009) and provides a possible landmark for the end of tectono-magmatic activity in the Paleoproterozoic craton of north-western Ghana.

\section{2-Crustal rheology, tectonic style and exhumation dynamics.}

The development of a partially molten, low-viscosity layer in the crust at the base of the orogeny is expected to cause a significant decrease in strength (Arzi, 1978; Vanderhaeghe and Teyssier, 2001a), with consequences on the deformation mode in the orogenic belt. Heterogeneous crustal thickening due to thrusting and widespread melting of the lower crust provide the conditions for the development of gravity-driven flow of the orogen. The formation of extensional detachments can be interpreted as a response to the buildup of gravitational potential energy induced by crustal thickening and lithospheric strength weakening due to partial melting (Dewey, 1988; Rey et al., 2001). The extensional shear zones accommodate horizontal sliding of large-scale upper crustal slices and vertical exhumation of partially molten lower crust, thus generating anatectic migmatite domes (Whitney et al., 2004). This evolution is typical of overthickened orogens and is widely documented in the Phanerozoic (e.g. Malavieille, 1993; Vanderhaeghe and Teyssier, 2001b) and in the Neoproterozoic (Norton, 1986). Gravity-driven flow develops 20-60 Ma after the onset of convergence. Extension may be a precursor to shortening through a near-continuous transition (e.g. Ledru et al., 2001, in the French Variscan belt), or both may develop synchronously due to mechanical decoupling between crustal slices of contrasting viscosity (e.g. Burchfiel et al., 1992, in the Himalayan belt, Vanderhaeghe and Teyssier, 2001a).

In north-western Ghana, metamorphic rocks suggest that D1 causes crustal thickening and is concomitant with partial melting of the lower crust. P-T-t paths (Fig. 7, b, and Block et al., XXX) show 
that supracrustal rocks buried at $>10$ kbar cross the solidus. Geochronological data reveal a close temporal relationship between anatexis and extension (Fig. 7). The observation of a "Tarkwaian type" basin folded during convergence and deposited on the hanging-wall of the detachment, suggests synconvergent extension and exhumation (Hodges et al., 1992, Jamieson et al, 2011); along with mechanical decoupling between the mechanically stronger clastic sediments and low-viscosity migmatitic paragneiss.

The development of anatectic migmatite domes subsequent to partial melting and to the formation of contrasting crustal layers implies specific clockwise P-T-t paths (Norlander et al., 2002). Near adiabatic decompression, or negative $\mathrm{dP} / \mathrm{dT}$ segments are expected in a context of crustal thinning, after crossing of the solidus at greater depth. Fast exhumation localised along high strain shear zones bounding the anatectic domes creates thermal antiforms in the crust, and significant peak temperature variations are expected across coeval isobaric terrains (Jamieson et al., 1998 ?, Brown et al., 2001). These predictions match the P-T-t-D paths obtained from amphibolite- to granulite-facies rocks of the study area (Fig. 7, b). The metamorphic record is consistent with exhumation of the lower crust in an anatectic migmatite dome.

In the Bole-Bulenga terrain, D3 fabrics are underlined by melt-bearing assemblages, while they carry greenschist- to amphibolite-facies mineral assemblages in surrounding lower-grade units. This provides evidence that high- and low-grade terrains were not at the same crustal level at that time. On the other hand, the interface between high- and low-grade rocks is folded around F3 folds (Fig. 5, Fig 9), suggesting that D3 post-dates exhumation. Field evidence therefore point to the exhumation and the final juxtaposition of different crustal slices during D3, i.e. in a convergent setting. Fabric transposition parallel to vertical planes characterises D3; and illustrates a changing tectonic style (Fig. 8). Alternations of migmatitic and sub-solidus gneisses of $\sim 20 \mathrm{~km}$ wavelength are elongated in a N-S direction in the Bole-Bulenga terrain, parallel to the D3 structural trend (Fig. 5). This succession of synforms and antiforms illustrates an undulation of the envelope separating low-viscosity migmatites from overlying rocks (Fig. 9). Such geometry may reflect syn-D3 amplification of gravity-driven instabilities developed in an extensional phase. Melting likely played a determining role in the development and amplification 
of the instabilities, which allowed for the extrusion of partially molten lower-crustal lithologies (Schlumann et al, 2008; Vanderhaege, O., 2009, Ganne et al., 2014). Melt is drained from migmatites in syn-D3 low permeability or extensional structures and feeds aligned (N-S) granite plutons (G3, Fig. 2) which emplaced in sub-solidus rocks at a higher structural level (Fig. 5, Brown and Solar, 1998a; 1998b).

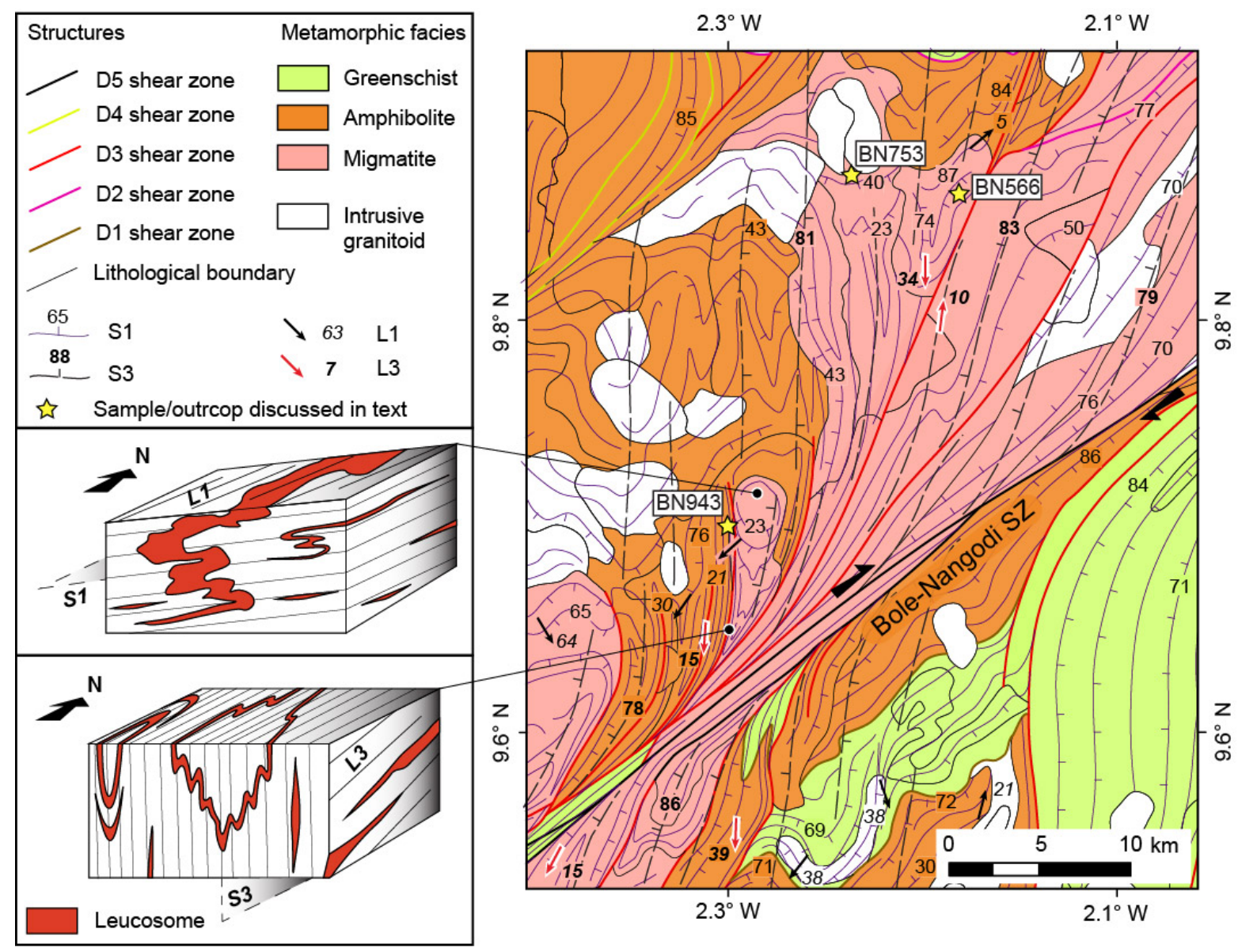

Figure 8. Detailed structural-metamorphic map of a horsetail structure along the Bole-Nangodi shear zone, in the Bole-Bulenga terrain (see figure 5 for localisation). Block diagrams illustrate the fabrics associated to D1 and D3 in high-grade rocks.

S3 vertical cleavage planes carry mineral stretching lineations (L3) with shallow plunges to the NNE or to the SSW, indicating a general horizontal stretching direction striking N0-N25 at the scale of the BoleBulenga terrain (Fig. 7, c). L2 stretching lineations respectively plunge moderately to the $\mathrm{N}$ and $\mathrm{S}$ in the Bulenga and Bole shear zones (respectively black and pink diamonds, Fig. 7, c). They indicate local 
extension directions which are similar to those revealed by L3 at a broader scale. We note that N-S directed extension is compatible with E-W directed shortening. and both may have synchronously developed within the same strain field.

As the lower crust is exhumed and starts cooling down, the rock rheology and deformation style change. Deformation is increasingly localised in low strength zones at lithological boundaries. Inherited structures re-activated under transcurrent regimes focus retrogression, alteration and strain, as the crust trends towards mechanical and thermal equilibrium, and final stabilisation (D4-D5).

\section{3-A geodynamic evolution model.}

The model proposed by De Kock $(2011 ; 2012)$ is not supported by our observations. Our results are inconsistent with the existence of two distinct metamorphic events (i.e. high-grade Eoeburnean and lowgrade Eburnean episodes), separated by a rifting phase which allowed the deposition of the "Maluwe basin”. It rather points to a continuous tectono-metamorphic evolution recorded in coeval high-grade and low-grade metamorphic terrains.

Rare eclogite-facies relics metamorphosed along a cold $\left(\sim 15^{\circ} \mathrm{C} / \mathrm{km}\right)$ apparent geothermal gradient (Block et al., XXX) reflect an early geodynamic setting, involving burial of cold supracrustal rocks. The amphibolite- to granulite-facies metamorphic overprint under contractional deformation is coeval with convergence and thickening during D1. The thickened crust affected by partial melting was then subjected to extensional gravitational collapse and exhumation of the migmatitic lower crust. The continuous transition from D1 to D2 is characterised by syn-convergence extension, exhumation and formation of an intra-orogen sedimentary basin, due to a growing contribution of gravity forces in the tectonic evolution.

In light of our complementary datasets, we propose that N-S directed extension (D2) and E-W horizontal shortening (D3) overlap in time and develop in the same strain field during large-scale, prolonged (minimum $30 \mathrm{Ma}$ ) anatexis.. The lateral sliding of low-grade upper crustal units accommodates vertical 
extrusion of the partially molten lower crust, which forms the core of an anatectic migmatitic dome. Horizontal contractional strain outlives extension, as illustrated by the re-folding of the envelope separating migmatites from suprasolidus rocks (Fig 9).

The shift from D1 to D3 represents a near instantaneous $90^{\circ}$ rotation in principal shortening directions. This requires an abrupt change in boundary stresses applied to the lithosphere. We suggest that this may be due to the tectonic juxtaposition of the Paleoproterozoic domains of northern Ghana with the cratonic bloc found in southwestern Burkina Faso, across the Wa-Lawra belt, between 2130 and 2110 Ma. This hypothesis is supported by (1) D3 strain being maximal at the interface between the Wa-Lawra belt and the Bole-Bulenga terrain, while attenuating with distance to this contact, in the Tumu Koudougou, Maluwe and Abulembire terrains; (2) terrains recording regional high-grade metamorphism at 21402130 Ma in NW Ghana, with no known equivalent in southern Burkina Faso. They confirm that northern Ghana formed a coherent crustal bloc at that period; (3) N-S and NE-SW structures (the dominant structural trend in western Burkina Faso - Côte d'Ivoire, and in Ghana respectively) merging in an interference zone along the margin of the Wa-Lawra belt. 

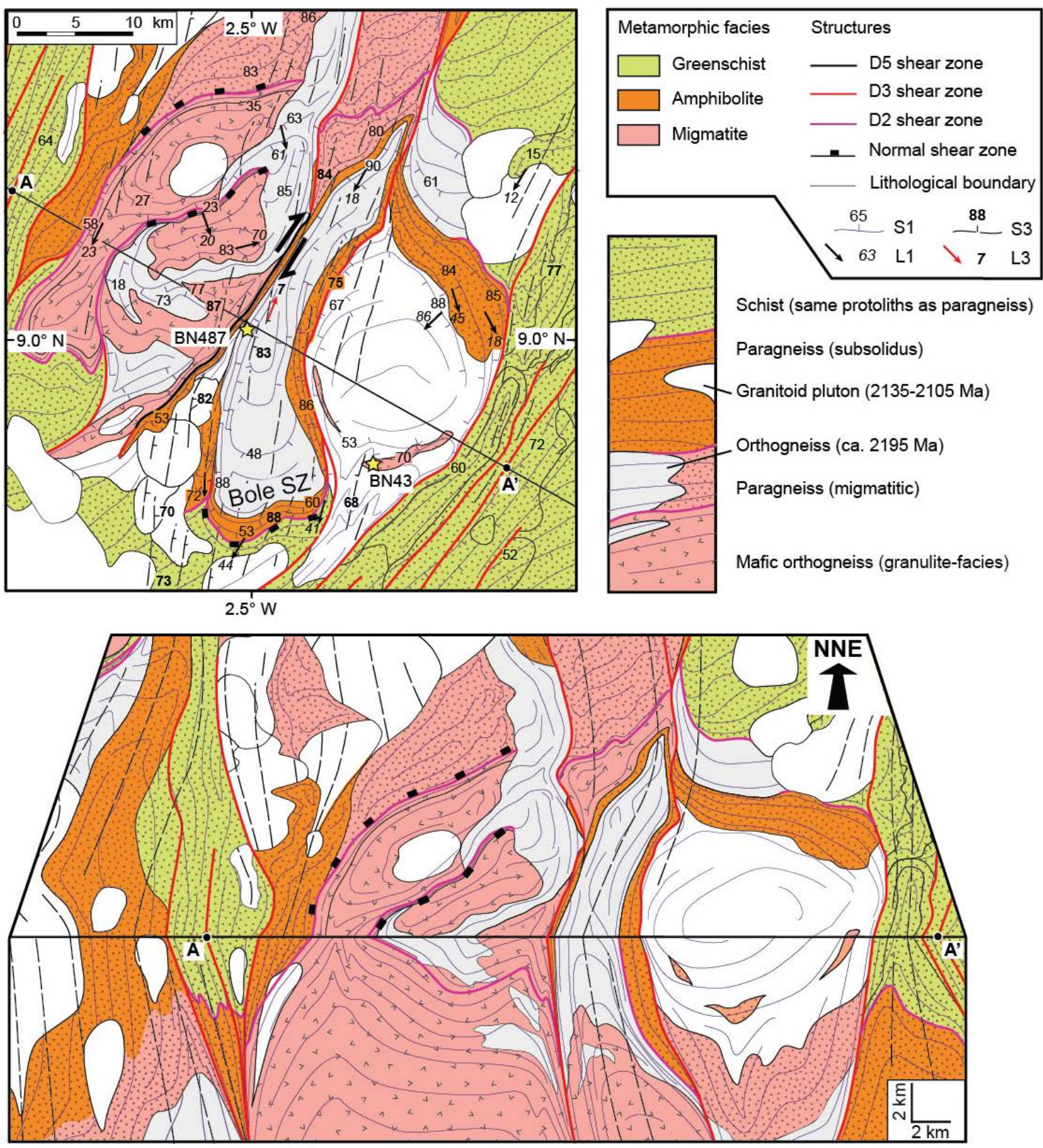

Figure 9. Top: Detailed structural-metamorphic map of the southern termination of the Bole-Bulenga terrain (see figure 5 for localisation). The stratigraphic column presents the relative position of the main lithological units in the orogenic crustal pile. Bottom: Bloc diagram illustrating the structural relationship between units. Cross-section is along a straight line through points A-A'. Lower-crustal rocks are exhumed at the core of domes bounded by shallow-dipping (D2) shear zones. Sub-vertical shear zones developed during D3 transpose early fabrics and form high-strain flanks of antiforms and synforms made of rock units from different crustal slices. 


\section{4-Implications for Paleoproterozoic geodynamics}

The Paleoproterozoic domain of north-western Ghana was subjected to dominantly horizontal tectonic forces during the Eburnean orogeny. They led to the juxtaposition of contrasting litho-tectonic terrains and to the formation of lateral baric metamorphic gradients across thrusts or extensional shear zones. These features contrast with the large isobaric metamorphic terrains (Percival and Skulski, 2000) and dome-and-basin strain patterns described in the Archean (Bouhailler et al. 1995; Choukroune et al., 1995; Collins et al., 1998) and Paleoproterozoic (Trap et al., 2008, Vidal et al., 2009). The structural and metamorphic record illustrates a gradual increase in the apparent geothermal gradient along with a shift in tectonic style induced by rheology changes. This Barrovian metamorphic cycle and associated deformation is consistent with evolution models of Phanerozoic collisional orogenic belts. In particular, anatectic migmatite domes bounded by extensional shear zones, resulting from the thermal weakening of a thickened orogenic crust, are hardly reported in the Archean and Paleoproterozoic (see Kisters et al., 2003, for a possible exception).

Hot orogeny models fail to account for the structural and metamorphic features recognized in northwestern Ghana. The apparent lack of typical extensional structures accommodating lower-crust exhumation has previously been interpreted as an absence of lateral gravitational potential energy gradients in ancient orogens (Gapais et al. 2009). This in turns was understood to reflect elevated Moho temperatures, which prevent significant heterogeneous crustal thickening in hot orogens (Rey and Houseman, 2006, Chardon et al., 2009). Although the architecture of the West African Craton resembles that of Archean cratons, we consider that crustal thickening and exhumation processes of the Eburnean orogeny share some similarities with modern orogens. This confirms that the Paleoproterozoic is a transitional period representative of a specific style of plate tectonics. This conclusion is supported by complementary evidence on the onset of a new behaviour of the continental lithosphere after the Neoarchean. These include increasing crustal recycling rates (Dhuime et al, 2012; Laurent et al. 2013), 
specific structural patterns (Cagnard et al., 2011), and a diversification of geothermal environments recorded by metamorphic rocks worldwide (Brown, 2007).

The collision model between Paleoproterozoic blocks in Ghana and Burkina Faso - Côte d'Ivoire is a working hypothesis which requires further testing. It has far-reaching implications for the geodynamic context of Paleoproterozoic continental crust formation and evolution. A weakness in our understanding of the Paleoproterozoic West African Craton lies in the lack of constraints required to propose a satisfying geodynamic model for the formation and stabilisation of such large volumes of juvenile continental crust in a short time span ( 200 Ma). Published studies have not allowed us to identify convincing age gradients, nor to establish strong correlations between "Eburnean” tectono-metamorphic events across the craton. The hypothesis of multiple juvenile continental blocs, tectonically assembled into larger masses resisting recycling, may stimulate further reflection on the stabilisation of the West African Craton, and on the geodynamics of the Paleoproterozoic Earth.

Appendix.

\section{U-Pb dating}

The internal structure of zircon and monazite grains were characterised by raster electron microscopy (REM) at Geosciences Environnement Toulouse using a JEOL SM-6360 OLV Scanning Electron Microscope, and at Université de Montpellier using an Environmental Scanning Electron Microscope FEI model.

Zircons were analysed at Université de Montpellier. The laser system consists in a Compex 102 (Lambda Physiks) 193nm excimer laser, coupled to Element XR sector field ICP-MS (for details on the analytical technique see Bosch et al., 2011). U-Th-Pb analyses were performed under helium, in a $15 \mathrm{~cm} 3$ circular shaped cell using an energy density of $12 \mathrm{~J} / \mathrm{cm} 2$ at a frequency of $4 \mathrm{~Hz}$. Laser spot sizes was $26 \mu \mathrm{m}$. Analyses were calibrated against the zircon standard G91500 (Wiedenbeck et al., 1995) which was used to correct the collected data for mass discrimination and inter-element fractionation. The $202 \mathrm{Hg}$ was used to monitor the $204 \mathrm{Hg}$ interference on $204 \mathrm{~Pb}$, but common $\mathrm{Pb}$ correction was not performed as this often resulted in over-correction, the 204 mass being largely dominated by 204Hg. Data presented in this study thus only report analyses for which no common $\mathrm{Pb}$ was detected.

Monazites were analysed at Goethe University FrankfurtUranium, thorium and lead isotopes were analyzed using a ThermoScientific Element 2 sector field ICP-MS coupled to a Resolution M-50 (Resonetics) $193 \mathrm{~nm}$ ArF excimer laser (ComPexPro 102F, Coherent) system, using the procedures described by Gerdes and Zeh (2006, 2009) with modifications explained in Zeh and Gerdes (2012). During this study the unknown monazite grains were analysed together with the standard zircon GJ-1 (Jackson et al., 2004), and with the standard monazites Moacir (Gasquet et al., 2010) and Manangotry (Horstwood et al., 2000). Most monazite grains (unknowns and standards) were ablated with a laser 
spot-size of $19 \mu \mathrm{m}$ diameter, but for high-U monazite, a smaller spot size of $12 \mu \mathrm{m}$ have been employed. Ablation was done with a repetition rate of $4 \mathrm{~Hz}$, and ca. $2 \mathrm{~J} \mathrm{~cm}^{-2}$ laser energy. Particle transport was performed in a $0.631 \mathrm{~min}^{-1} \mathrm{He}$ stream, which was mixed directly after the ablation cell with $0.021 \mathrm{~min}^{-}$ ${ }^{1} \mathrm{~N}_{2}$ and $0.83 \mathrm{l} \mathrm{min}^{-1}$ Ar prior to introduction into the Ar plasma of the SF-ICP-MS. Signal was tuned for maximum sensitivity for $\mathrm{Pb}$ and $\mathrm{U}$ while keeping oxide production, monitored as ${ }^{254} \mathrm{UO} /{ }^{238} \mathrm{U}$, below $0.2 \%$. The sensitivity achieved was in the range of ca. $12900 \mathrm{cps} / \mu \mathrm{g} \mathrm{g}{ }^{-1}$ for ${ }^{238} \mathrm{U}$ with a $33 \mu \mathrm{m}$ spot size, at $5.0 \mathrm{~Hz}$ and $5 \mathrm{~J} \mathrm{~cm}^{-2}$ laser energy (obtained on the standard zircon GJ1). Sample surfaces were cleaned directly before each analysis by three pulses pre-ablation. Raw data were corrected offline for background signal, common $\mathrm{Pb}$, laser induced elemental fractionation, instrumental mass discrimination, and time-dependent elemental fractionation of $\mathrm{Pb} / \mathrm{U}$ using an in-house MS ExcelC spreadsheet program (Gerdes and Zeh, 2006, 2009). The common-Pb correction was carried out when the common- $\mathrm{Pb}$ uncorrected ${ }^{207} \mathrm{~Pb} /{ }^{206} \mathrm{~Pb}$ was significantly higher than the corrected ${ }^{207} \mathrm{~Pb} /{ }^{206} \mathrm{~Pb}$. For most analyses the common $\mathrm{Pb}$ level (quoted here as ${ }^{206} \mathrm{~Pb}$ common of total ${ }^{206} \mathrm{~Pb}$ ) was below $0.2 \%$. Common$\mathrm{Pb}$ correction was carried out by using the ${ }^{202,204} \mathrm{Hg}$ interference- and background-corrected ${ }^{204} \mathrm{~Pb}$ signal, and a model Pb composition (Stacey and Kramers, 1975). The interference of ${ }^{204} \mathrm{Hg}$ (ca. $250 \mathrm{cps}$; counts per second, during our sessions) on mass 204 was estimated using a ${ }^{204} \mathrm{Hg} /{ }^{202} \mathrm{Hg}$ ratio of 0.2299 and the measured ${ }^{202} \mathrm{Hg}$. Laser induced elemental fractionation and instrumental mass discrimination were corrected by normalization to the reference zircon GJ-1 (primary standard). Potential matrix effects were controlled by multiple measurements of the standard monazites Moacir and Managotry (secondary standards). Prior to the normalization, the drift in inter-elemental fractionation $(\mathrm{Pb} / \mathrm{U})$ during $21 \mathrm{~s}$ of sample ablation was corrected for the individual analysis. The correction was done by applying a linear regression through all measured ratios, excluding the outliers ( \pm 2 sigma standard deviation; 2 SD), and using the intercept with the $y$-axis as the initial ratio (=intercept method). The total offset of the measured drift-corrected ${ }^{206} \mathrm{~Pb} /{ }^{238} \mathrm{U}$ ratio from the“true” ID-TIMS value $(0.0982 \pm 0.0004$; ID-TIMS GUF-value) of the analyzed GJ-1 grain was ca.11\%. Reported uncertainties $(2 \sigma)$ of the ${ }^{206} \mathrm{~Pb} /{ }^{238} \mathrm{U}$ ratio were propagated by quadratic addition of the external reproducibility (2 SD \%) obtained from standard GJ-1 $(\mathrm{n}=11 ; 2 \mathrm{SD} 1.23 \%)$ during the analytical session, and the within-run precision of each analysis (2 SE \%; standard error). Reproducibility of the ${ }^{207} \mathrm{~Pb} /{ }^{206} \mathrm{~Pb}$ ratio depends strongly on counting statistic (see Gerdes \& Zeh, 2009), as well as on the common-Pb content. To account for both, the uncertainty on ${ }^{207} \mathrm{~Pb} /{ }^{206} \mathrm{~Pb}$ signal were propagated by quadratic addition of the outlier corrected ${ }^{207} \mathrm{~Pb} /{ }^{206} \mathrm{~Pb}$ within-run precision (2 SE\%), a ${ }^{207} \mathrm{~Pb}$ signal dependent factor, and an factor which takes the amount of common$\mathrm{Pb}$, and the uncertainties of model $\mathrm{Pb}$ composition into account (Gerdes \& Zeh, 2009). The ${ }^{207} \mathrm{~Pb} /{ }^{235} \mathrm{U}$ ratio is derived from the normalized and error propagated ${ }^{207} \mathrm{~Pb} /{ }^{206} \mathrm{~Pb}$ and ${ }^{206} \mathrm{~Pb} /{ }^{238} \mathrm{U}$ ratios, assuming a ${ }^{238} \mathrm{U} /{ }^{235} \mathrm{U}$ natural abundance ratio of 137.88 and the uncertainties of both ratios. The standard zircon GJ1 $(n=11)$ measured during this study yield a Concordia ages of $604.1 \pm 2.7 \mathrm{Ma}(\mathrm{n}=11, \mathrm{MSWD}=0.55$, Probability of fit $=0.95$ ). Multiple measurements of the standard monazite Moacir yield a Concordia age of $500.7 \pm 2.5(\mathrm{n}=11, \mathrm{MSWD}=1.4$, Probability of fit $=0.12)$ and of the standard monazite Manangotry a Concordia age of $552.3 \pm 2.8(\mathrm{n}=11$, MSWD=1.18, Probability of fit $=0.26)$ which are within error of published data (Horstwood et al., 2000; Gasquet et al., 2010).

The data were plotted using the software ISOPLOT (Ludwig, 2001). 
Abouchami, W., Boher, M., Michard, A., Albarede, F., 1990. A major 2.1 Ga event of mafic magmatism in West Africa; an early stage of crustal accretion. Journal of Geophysical Research, B, Solid Earth and Planets 95 (17), 605-617, 629.

Affaton, P., Sougy, J., Trompette, R., 1980. The tectono-stratigraphic relationships between the upper Precambrian and lower Paleozoic Volta Basin and the pan-african Dahomeyide orogenic belt (West Africa). American Journal of Science. 280, 3, 224-248.

Arnould, M., 1961. Etude géologique des migmatites et des granites précambriens du nord-est de la Côte d’Ivoire et de la Haute-Volta méridionale. Mémoires du BRGM, 176pp.

Baratoux, L., Metelka, V., Naba, S., Jessell, W.M., Gregoire, M., Ganne, J., 2011. Juvenile paleoproterozoic crust evolution during the Eburnean orogeny $(-2.2-2.0 \mathrm{Ga})$, western Burkina Faso. Precambrian Research 191, 18-45.

Bessoles, B., 1977. Géologie de l’Afrique. Le craton Ouest-Africain Mémoires. BRGM, Paris, p. 88

Boher, M., Abouchami, W., Michard, A., Albarède, F., Arndt, N. T., 1992. Crustal growth in West Africa at 2.1 Ga. Journal of Geophysical Research, B, Solid Earth and Planets 97, 345-369.

Bonhomme, M., 1962. Contribution a l'etude geochronologique de la plate-forme de l'Ouest Africain. Annals de la Faculte des Sciences de Universite de Clermont- Ferrand Geol. Mineral 5, 62.

Bouhallier, H., Chardon, D., Choukroune, P., 1995. Strain patterns in Archaean dome-and-basin structures: The Dharwar craton (Karnataka, South India). Earth and Planetary Science Letters, 135(1), 57-75.

Brown, M. and Solar, G. S., 1998a. Granite ascent and emplacement during contractional deformation in convergent orogens. Journal of Structural Geology, 20, 9/10, 1365-1393.

Brown, M., and Solar, G. S., 1998b. Shear-zone systems and melts: feedback relations and selforganization in orogenic belts. Journal of Structural Geology, 20, 2, 211-227.

Brown, M., 2007. Metamorphic conditions in orogenic belts: a record of secular change. International Geology Review, 49, 193-234

Burchfiel, B. C., Zhiliang, C., Hodges, K. V., Yuping, L., Royden, L. H., Changrong, D., 1992. The South Tibetan detachment system, Himalayan orogen: Extension contemporaneous with and parallel to shortening in a collisional mountain belt (Vol. 269). Geological Society of America.

Chardon, D., Gapais, D., Cagnard, F., 2009. Flow of ultra-hot orogens: a view from the Precambrian, clues for the Phanerozoic. Tectonophysics, 477(3), 105-118.

Choukroune, P., Bouhallier, H., Arndt, N. T., 1995. Soft lithosphere during periods of Archaean crustal growth or crustal reworking. Geological Society, London, Special Publications, 95(1), 67-86.

Collins, A. S., Reddy, S. M., Buchan, C., Mruma, A., 2004. Temporal constraints on Palaeoproterozoic eclogite formation and exhumation (Usagaran Orogen, Tanzania). Earth and Planetary Science Letters, 224, 1, 175-192.

Collins, W. J., Van Kranendonk, A. M., Teyssier, C., 1998. Partial convective overturn of Archaean crust in the east Pilbara Craton, Western Australia: driving mechanisms and tectonic implications. Journal of Structural Geology, 20(9), 1405-1424. 
De Kock, G.S., Armstrong, R.A., Siegfried, H.P., Thomas, E., 2011. Geochronology of the Birim Supergroup of the West African Craton in the Wa-Bolé region of central-west Ghana: implications for the stratigraphic framework. Journal of African Earth Sciences 59, 1-40.

De Kock, G.S. Theveniaut, H., Botha, P.W., Gyapong, W., 2012. Timing the structural events in the Palaeoproterozoic Bolé-Nangodi belt terrane and adjacent Maluwe basin, West African Craton, in central-west Ghana. Journal of African Earth Sciences 65, 1-24.

De Kock, G.S. Theveniaut, H., Botha, P.W., Gyapong, W., 2009. Geological map explanation—map sheet 0803B (1:100,000). CGS/BRGM/Geoman. Geological Survey Department of Ghana.

Delor, C., Siméon, Y., Vidal, M., Zéadé, Z., Koné, Y., Adou, M., Dibouahi, J., Bi-Irié, D., Yao, B.D., N'Da, D., Pouclet, A., Konan, G., Diaby, I., Chiron, J.C., Dommanget, A., Kouamelan, A., Peucat, J.J., Cocherie, A., Cautru, J.P., 1995b. Carte géologique de la Côte-d'Ivoire 1/ 200000, feuille de Nassian. Ministère des Mines et de l'Energie. DMG, Abidjan, Côted'Ivoire.

England, P. C., and Thompson, A. B., 1984. Pressure-temperature-time paths of regional metamorphism I. Heat transfer during the evolution of regions of thickened continental crust. Journal of Petrology, 25(4), 894-928.

Dewey, J. F., 1988. Extensional collapse of orogens. Tectonics, 7(6), 1123-1139.

Feybesse, J.-L., Billa, M., Guerrit, C., Duguey, E., Lescuyer, J.-L., Milesi, J.P., Bouchot, V., 2006. The paleoproterozoic Ghanaian province : Geodynamic model and ore controls, including regional stress modeling. Precambrian Research 149, 149-196.

Ganne, J., Gerbault, M., Block, S., 2014. Thermo-mechanical modeling of lower crust exhumationconstraints from the metamorphic record of the Palaeoproterozoic Eburnean orogeny, West African Craton. Precambrian Research.

Hein, K.A.A., 2010. Succession of structural events in the Goren greenstone belt (Burkina Faso): implications for West African tectonics. Journal of African Earth Sciences 56, 83-94.

Hodges, K. V., Parrish, R. R., Housh, T. B., Lux, D. R., Burchfiel, B. C., Royden, L. H.,Chen, Z., 1992. Simultaneous Miocene extension and shortening in the Himalayan orogen. Science, 258(5087), 1466-1470.

Jamieson, R. A. and Beaumont, C., 2011. Coeval thrusting and extension during lower crustal ductile flow-implications for exhumation of high-grade metamorphic rocks. Journal of Metamorphic Geology, 29(1), 33-51.

Jessell, M.W., Prince O. Amponsah, Lenka Baratoux, Daniel K. Asiedu, Geoffrey K. Loh, Jérôme Ganne. 2012. Crustal-scale transcurrent shearing in the Paleoproterozoic Sefwi-Sunyani-Comoé region, West Africa, Precambrian Research, 212-213, 155-168.

Kisters, A. F., Stevens, G., Dziggel, A., Armstrong, R. A., 2003. Extensional detachment faulting and core-complex formation in the southern Barberton granite-greenstone terrain, South Africa: evidence for a 3.2 Ga orogenic collapse. Precambrian Research, 127(4), 355-378.

Laurent, O., Doucelance, R., Martin, H., Moyen, J. F., 2013. Differentiation of the late-Archaean sanukitoid series and some implications for crustal growth: Insights from geochemical modelling on the Bulai pluton, Central Limpopo Belt, South Africa. Precambrian Research, 227, 186-203.

Lahondère, D., Thiéblemont, D., Tegyey, M., Guerrot, C., Diabate, B., 2002. First evidence of early Birimian $(2.21 \mathrm{Ga})$ volcanic activity in Upper Guinea: the volcanics and associated rocks of the Niani suite. Journal of African Earth Sciences, 35(3), 417-431. 
Ledru, P., Courrioux, G., Dallain, C., Lardeaux, J. M., Montel, J. M., Vanderhaeghe, O., Vitel, G., 2001. The Velay dome (French Massif Central): melt generation and granite emplacement during orogenic evolution. Tectonophysics, 342(3), 207-237.

Lemoine, S., Tempier, P., Bassot, J.P., Caen-Vachette, M., Vialette, Y., 1990. The Burkinian orogenic cycle, precursor of the Eburnian orogeny in West Africa. Geological Journal, vol 25, 171-188.

Malavieille, J., 1993. Late orogenic extension in mountain belts: insights from the Basin and Range and the late Paleozoic Variscan belt. Tectonics, 12(5), 1115-1130.

Metelka, V., Baratoux, L., Naba, S., Jessell, W.M., 2011. A geophysically constrained litho-structural analysis of the Eburnean greenstone belts and associated granitoid domains, western Burkina Faso. Precambrian Research 190, 48-69.

Naba, S., Lompo, M., Debat, P., Bouchez, J.L., Beziat, D., 2004. Structure and emplacement model for late-orogenic Paleoproterozoic granitoids: the Tenkodogo-Yamba elongate pluton (Eastern Burkina Faso). J. Afr. Earth Sci. 38, 41-57.

Norlander, B. H., Whitney, D. L., Teyssier, C., Vanderhaeghe, O., 2002. Partial melting and decompression of the Thor-Odin dome, Shuswap metamorphic core complex, Canadian Cordillera. Lithos, 61(3), 103-125.

Percival, J. A., and Skulski, T., 2000. Tectonothermal evolution of the northern Minto Block, Superior Province, Quebec, Canada. The Canadian Mineralogist, 38(2), 345-378.

Perrouty, S., Aillères, L., Jessell, M. W., Baratoux, L., Bourassa, Y., Crawford, B., 2012. Revised Eburnean geodynamic evolution of the gold-rich southern Ashanti Belt, Ghana, with new field and geophysical evidence of pre-Tarkwaian deformations. Precambrian Research 204- 205, 12- 39.

Pigois, J.P., Groves, D.I., Fletcher, I.R., McNaughton, N.J., Snee, L.W., 2003. Age constraints on Tarkwaian palaeoplacer and lode-gold formation in the Tarkwa- Damang district, SW Ghana. Mineralium Deposita 38, 695-714.

Rey, P., Vanderhaeghe, O., Teyssier, C., 2001. Gravitational collapse of the continental crust: definition, regimes and modes. Tectonophysics, 342(3), 435-449.

Roques, M., 1948. Le Précambrien de l'Afrique occidentale française. Bull. Soc. Géol. Fr., Paris, $5^{\mathrm{e}}$ série, t. XV, fasc. 8-9, pp. 528-546.

Rubatto, D., and Hermann, J., 2001. Exhumation as fast as subduction?. Geology, 29, 1, 3-6.

Sagatzky, J., 1954. La géologie et les ressources minières de la Haute-Volta méridionale. Bull. Dir. Fédér. Mines Géologie A.O.F., Dakar, 224p.

Siegfried, P., Clarke, B., Agenbacht, A., Delor, C., Grantham, G., De Kock, G.S., Van Rooyen, R.C., 2009. Geological map explanation—map sheet 0903D (1:100,000). CGS/BRGM/Geoman. Geological Survey Department of Ghana (GSD).

Schlumann, K., Lexa, O., Štípská, P., Racek, M., Tajčmanová, L., Konopásek, J., Edel, J.-B., Peschler, A., Lehmann, J., 2008. Vertical extrusion and horizontal channel flow of orogenic lower crust : key exhumation mechanisms in large hot orogens? Journal of Metamorphic Geology, 26, 273-297. 
Taylor, P.N., Moorbath, S., Leube, A., Hirdes, W., 1992. Early Proterozoic crustal evolution in the birimian of Ghana: constraints from geochronology and isotope geochemistry. Precambrian Research 56, 97-111.

Théveniaut, H., Ndiaye, P. M., Buscail, F., Couëffé, R., Delor, C., Fullgraf, T., Goujou, J. C., 2010. Notice Explicative de la Carte Géologique du Sénégal Oriental à 1/500000, Ministère des Mines, de l'Industrie, de l’Agro-Industrie et des PME, Direction des Mines et de la Géologie, Dakar, 122 p.

Thomas, E., De Kock, G.S., Baglow, N., Viljoen, J., Siaka, Z., 2009. Geological map explanationmap sheet 0903D (1:100,000). CGS/BRGM/Geoman. Geological Survey Department of Ghana

(GSD).

Tshibubudze, A., Hein, K.A.A., Marquis, P., 2009. The Markoye shear zone in NE Burkina Faso. Journal of African Earth Sciences 55, 245-256.

Vanderhaeghe, O., 2009. Migmatites, granites and orogeny: Flow modes of partially-molten rocks and magmas associated with melt/solid segregation in orogenic belts. Tectonophysics, 477, 119-134.

Vanderhaeghe, O., and Teyssier, C., 2001a. Crustal-scale rheological transitions during late-orogenic collapse. Tectonophysics, 335(1), 211-228.

Vanderhaeghe, O., and Teyssier, C., 2001b. Partial melting and flow of orogens. Tectonophysics, 342(3), 451-472.

Vidal, M., Gumiaux, C., Cagnard, F., Pouclet, A., Ouattara, G., Pichon, M., 2009. Evolution of a Paleaoproterozoic « weak type » orogeny in the West African Craton (Ivory Coast). Tectonophysics 477, 145-159.

Whitney, D. L., Teyssier, C., Vanderhaeghe, O., 2004. Gneiss domes and crustal flow. Gneiss domes in orogeny, 380, 15.

Willett, S. D. and Brandon, M. T., 2002. On steady states in mountain belts. Geology, 30, 2, 175-178.

Zitsmann, A., Kiessling, R., Loh, G., 1997. Geology in the Bui belt area in Ghana. In: Zitsmann, A. (Ed.), Geological, Geophysical and Geochemical Investigations in the Bui Belt Area in Ghana. Geologische Jahrbuch, Reihe B, vol. 88, pp. 7-112. 